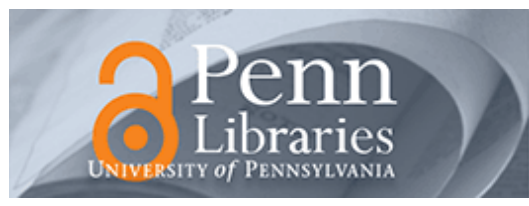

University of Pennsylvania ScholarlyCommons

Publicly Accessible Penn Dissertations

2019

\title{
Private Communication Among Competitors And Public Disclosure
}

John David Kepler

University of Pennsylvania, jdkepler@gmail.com

Follow this and additional works at: https://repository.upenn.edu/edissertations

Part of the Accounting Commons

\section{Recommended Citation}

Kepler, John David, "Private Communication Among Competitors And Public Disclosure" (2019). Publicly Accessible Penn Dissertations. 3278.

https://repository.upenn.edu/edissertations/3278

This paper is posted at ScholarlyCommons. https://repository.upenn.edu/edissertations/3278

For more information, please contact repository@pobox.upenn.edu. 


\title{
Private Communication Among Competitors And Public Disclosure
}

\begin{abstract}
Conventional wisdom suggests that firms benefit from coordinating pricing and production decisions. One way firms can coordinate such decisions is through private communication. However, private communication between competing firms is typically not allowed by anti-trust regulations. In the absence of private communication, theories at the intersection of accounting and industrial organization suggest that competing firms can use public disclosure to coordinate. These theories predict a substitutive relation between private communication and public disclosure that serves a coordinating role: private communication reduces the need to coordinate via public disclosure. I exploit data on the extent of private communication among competing firms in strategic alliances to examine how private communication manifests in firms' public disclosure decisions. Consistent with theoretical predictions, I find that firms that enter into strategic alliances with competitors reduce their public disclosure about expected future business conditions, including forecasts of demand and production levels, and that the reduction is most pronounced for firms in alliances that entail more extensive private communication.
\end{abstract}

\section{Degree Type}

Dissertation

Degree Name

Doctor of Philosophy $(\mathrm{PhD})$

Graduate Group

Accounting

First Advisor

Christopher Armstrong

\section{Keywords}

Coordination, Disclosure, Joint Ventures, Private Communication, Strategic Alliances

\section{Subject Categories}

Accounting 
PRIVATE COMMUNICATION AMONG COMPETITORS AND PUBLIC DISCLOSURE

John D. Kepler

A DISSERTATION

in

Accounting

For the Graduate Group in Managerial Science and Applied Economics

Presented to the Faculties of the University of Pennsylvania

in

Partial Fulfillment of the Requirements for the

Degree of Doctor of Philosophy

2019

Supervisor of Dissertation

Christopher Armstrong, EY Professor of Accounting

Graduate Group Chairperson

Catherine Schrand, Celia Z. Moh Professor of Accounting

Dissertation Committee

Christopher Armstrong, EY Professor of Accounting

$\underline{\text { Robert Holthausen, the Nomura Securities Company Professor of Accounting \& Finance }}$

Daniel Taylor, Associate Professor of Accounting 
This dissertation is dedicated to the three people who have impacted my life for the better more than any others: my wife Victoria, my father Jerry, and my late mother Terri. This dissertation would not have been possible without each of their sacrifices, encouragement, advice, and support. 


\section{ACKNOWLEDGMENT}

I am very grateful to the members of my dissertation committee for their support, guidance, and insight: Chris Armstrong (chair), Bob Holthausen, and Dan Taylor. I also thank Salman Arif, Matt Bloomfield, Thomas Bourveau, Brian Bushee, Saikat Chaudhuri, Carlos Corona, Carolyn Deller, Paul Fischer, Jon Glover, Wayne Guay, Luzi Hail, Mirko Heinle, Chris Ittner, Zach Kaplan, Rick Lambert, Tanya Paul, Delphine Samuels, Harbir Singh, Kevin Smith, Phil Stocken, Jake Thornock, David Tsui, Ro Verrecchia, Premal Vora, Christina Zhu, a strategic alliance antitrust partner at Skadden, Arps, Slate, Meagher \& Flom LLP and Affiliates, as well as seminar participants at Duke, Indiana, Massachusetts Institute of Technology, New York University, Northwestern, University of Washington, Stanford, University of North Carolina, University of Michigan, University of Pennsylvania, University of Southern California, the 2018 Deloitte Doctoral Consortium, and the 2018 CMU Accounting Mini Conference for helpful discussion and comments. I thank the authors of Jennings, Lee, and Matsumoto (2017) for providing data used in their paper.

I gratefully acknowledge the financial support of the Wharton School of the University of Pennsylvania, the Deloitte Foundation Doctoral Fellowship, and Laventhol \& Horwath Accounting Scholarship. 


\begin{abstract}
PRIVATE COMMUNICATION AMONG COMPETITORS AND PUBLIC

DISCLOSURE

John Kepler

Christopher Armstrong
\end{abstract}

Conventional wisdom suggests that firms benefit from coordinating pricing and production decisions. One way firms can coordinate such decisions is through private communication. However, private communication between competing firms is typically not allowed by anti-trust regulations. In the absence of private communication, theories at the intersection of accounting and industrial organization suggest that competing firms can use public disclosure to coordinate. These theories predict a substitutive relation between private communication and public disclosure that serves a coordinating role: private communication reduces the need to coordinate via public disclosure. I exploit data on the extent of private communication among competing firms in strategic alliances to examine how private communication manifests in firms' public disclosure decisions. Consistent with theoretical predictions, I find that firms that enter into strategic alliances with competitors reduce their public disclosure about expected future business conditions, including forecasts of demand and production levels, and that the reduction is most pronounced for firms in alliances that entail more extensive private communication. 
ACKNOWLEDGMENT ........................................................................................

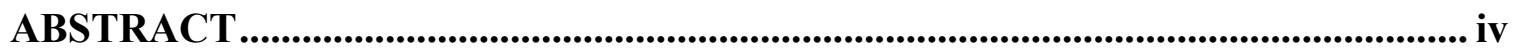

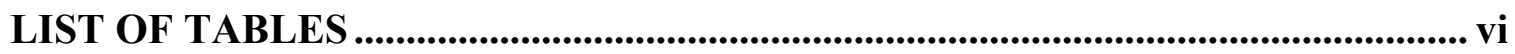

LIST OF ILLUSTRATIONS ..................................................................................... vii

PRIVATE COMMUNICATION AMONG COMPETITORS AND PUBLIC

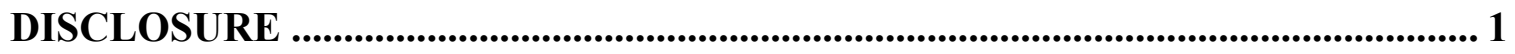

Introduction ..................................................................................................................................................

Background and Empirical Predictions ...........................................................................................................9

Sample Construction and Descriptive Statistics................................................................................................15

Research Design and Results...........................................................................................................................22

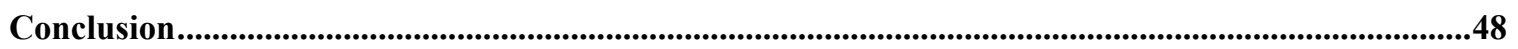

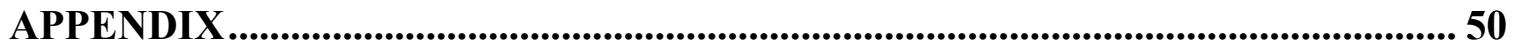

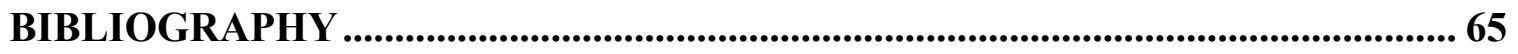




\section{LIST OF TABLES}

Table 1, Panel A: Strategic Alliance Descriptive Statistics; Strategic Alliance Industry Distribution.

Table 1, Panel B: Strategic Alliance Descriptive Statistics; Strategic Alliance

Characteristics.

Table 2, Panel A: Descriptive Statistics; Pooled Sample.......................................20

Table 2, Panel B: Descriptive Statistics; Strategic Alliance Sample........................21

Table 3: Strategic Alliances and Voluntary Disclosure......................................27

Table 4: Strategic Alliances and Topic of Public Disclosure................................28

Table 5, Panel A: Cross Sectional Tests: The Degree of Private Communication in Strategic Alliances; Quantitative Measure of Public Disclosure..................................32

Table 5, Panel B: Cross Sectional Tests: The Degree of Private Communication in Strategic Alliances; Topic of Public Disclosure....................................................32

Table 6. Falsification Test: Limited Private Communication in Strategic Alliances..........34

Table 7, Panel A: Cross Sectional Tests: Industry Characteristics; Quantitative Measure of Public Disclosure

Table 7, Panel B: Cross Sectional Tests: Industry Characteristics; Topic of Public Disclosure. .38

Table 8, Panel A: Quasi-Natural Experiment: Combined Reporting Rules; Descriptive Statistics.

Table 8, Panel B1: Quasi-Natural Experiment: Combined Reporting Rules; Combined Reporting Rules and Differences in Strategic Alliance Activity....

Table 8, Panel B2: Quasi-Natural Experiment: Combined Reporting Rules; Univariate Differences of Public Disclosure.

Table 8, Panel C: Quasi-Natural Experiment: Combined Reporting Rules; Generalized Difference-in-Differences 


\section{LIST OF ILLUSTRATIONS}

Figure 1, Panel A: New Strategic Alliance Announcements per Year; All Strategic

Alliances......................................................................................................17

Figure 1, Panel B: New Strategic Alliance Announcements per Year; Strategic Alliance Activity by Alliance Type..................................................................................................17

Figure 2: Combined Reporting Rules Staggered Adoption.................................40

Figure 3, Panel A: Strategic Alliances, Trading Volume, and Abnormal Returns; Strategic Alliance Announcement Normalized Trading Volume..................................47

Figure 3, Panel B: Strategic Alliances, Trading Volume, and Abnormal Returns; Strategic Alliance Announcement Abnormal Returns.........................................48 
Private Communication among Competitors and Public Disclosure

\section{Introduction}

A long line of literature examines the monitoring and valuation roles of firms' public disclosures-i.e., the roles of disclosure in mitigating agency conflicts and facilitating valuation by capital providers (see Armstrong, Guay, and Weber, 2010; Leuz and Wysocki, 2016 for reviews). In contrast, the coordination role of firms' public disclosures - i.e., the role of disclosure in facilitating coordination of pricing and production decisions among competitors - has received considerably less attention. In this paper, I examine whether and the extent to which private communication among competitors substitutes for the coordination role of public disclosure.

A large body of theory at the intersection of accounting and industrial organization suggests that competitors use public disclosures to coordinate their production and pricing decisions. For example, Fried (1984, p. 375) argues that competing firms are mutually better off by publicly disclosing information about their expected business conditions "not only because firms are better off when they learn about their competition but also because they can be better off when their competition learns about them." In particular, by learning about competitors' production decisions, firms can adjust their own production to avoid over- or under-production and increase their collective profits. For instance, firms might publicly disclose that product demand is weaker than expected to encourage competitors 
to restrain their own production (see also Vives, 1984; Clinch and Verrecchia, 1997; Bertomeu and Liang, 2015; Arya and Mittendorf, 2016). ${ }^{1}$

Importantly, these theories about the coordination role of public disclosure are predicated on the notion that competing firms cannot credibly exchange information privately. For example, private communication of quantity and price information among competitors is likely to invite considerable scrutiny from regulators, such as the United States Department of Justice (DOJ) and the Federal Trade Commission (FTC). If firms can credibly exchange information privately, public disclosure loses its value as a coordination mechanism (e.g., Gigler, 1994; Reis and Stocken, 2007). Consequently, private communication between competitors reduces - and, in the limit, eliminates - the usefulness of public disclosure as a coordination mechanism.

Reflecting concerns that firms' public disclosures can be used to facilitate coordination, the DOJ and FTC have explicitly stated an interest in investigating whether competitors use public disclosures to coordinate production and pricing decisions (e.g., OECD, 2010). For example, in a recent case, the FTC accused Stone Container Corporation of using a management forecast to publicly disclose information about its future production plans, thereby allowing its competitors to coordinate their production quantities and ultimately increase prices for consumers (OECD, 2010, p. 304). The FTC concluded that this disclosure contained no information other than an implicit proposal to its competitors that, if accepted, would foster illegal coordination. In another case, the FTC alleged that

\footnotetext{
${ }^{1}$ In the context of these models, one can think of the "coordination benefits" of disclosure as the opposite of the more familiar "proprietary costs" of disclosure, which are often characterized as a negative side effect of firms' public disclosures. Analogously, the coordination role of disclosure entails a direct, competitive benefit of firms' disclosures.
} 
U-Haul used its earnings call to provide information about its future pricing strategy, knowing that its key competitors would be monitoring the call (OECD, 2010). Although economic theory predicts and anecdotal evidence suggests a coordination role for public disclosure systematic empirical evidence about the coordination role of public disclosure is limited. ${ }^{2}$

In this paper, I use data on the existence and structure of approximately 115,000 strategic alliances between 1994 and 2016 to examine how private communication among competitors influences their public disclosure decisions. Strategic alliances-in which firms pool their complementary resources and exercise joint control over certain business activities - provide a direct channel for credible private communication (e.g., Gulati and Singh, 1998; Ménard, 2004; Schoenfeld, 2018). For example, Schoenfeld (2018) shows that joint venture agreements - one of the most common forms of strategic alliancescontractually require firms to share a variety of private information among participants. ${ }^{3}$ To the extent that alliance partners are also engaged in activities in which they currently or may potentially compete, these direct private communication channels can also be usedin lieu of public disclosure-for coordination purposes. Importantly, private communication in the context of strategic alliances is generally less likely to run afoul of

\footnotetext{
${ }^{2}$ While antitrust regulators tend to focus their enforcement efforts on reducing illicit coordination among competitors (e.g., price-fixing cartels), coordination among firms represents a continuum and can take many forms, including facilitating coordination of investment activities that are more innocuous from the perspective of consumers, but still improve the allocation of resources among firms.

${ }^{3}$ Strategic alliances have surged in recent years: recent estimates indicate that the thousand largest public U.S. firms earn $40 \%$ of their revenue through strategic alliances and that $60 \%$ of U.S. CEOs have current or future plans to enter into strategic alliances with competitors (ASAP, 2002, p. 8; PwC, 2016). Furthermore, Bamford (2017) reports that global corporate investment in joint ventures currently exceeds $\$ 5$ trillion per year, recently surpassing the global M\&A market in terms of deal value (J.P. Morgan, 2017).
} 
antitrust regulations, "as the private disclosure of price information may be commercially justifiable between [...] joint venture participants" (OECD, 2010, p. 108). ${ }^{4}$

Several studies in the industrial organization literature highlight the importance of private communication among partners as a byproduct of strategic alliances. For instance, Ménard (2004) characterizes strategic alliances as "cooperative games" among competitors, with partner-specific communication that both facilitates coordination of alliance-related activities and creates "knowledge spillovers" due to the information that firms obtain about their partners' non-alliance activities (see also, Williamson, 1985, 1991). In addition, prior research finds that strategic alliances that require more extensive private communication - e.g., regularly scheduled meetings, co-location of employees, the right to examine and audit all relevant records, etc. - - tend to last longer and are less prone to opportunistic behavior by partners (e.g., Parkhe, 1993; Thomas and Trevino, 1993; Reuer and Koza, 2000). Thus, an important byproduct of strategic alliances is that they establish a private communication channel among firms that endow firms with information about participating firms.

A newfound ability to privately communicate through a strategic alliance should reduce the coordination benefits of public disclosure. Consequently, to the extent that firms use public disclosure to coordinate their production and pricing decisions, I expect a reduction in firms' public disclosures after forming strategic alliances. Consistent with this

\footnotetext{
${ }^{4}$ Antitrust regulators also explicitly acknowledge that strategic alliances and joint ventures between firms can act as a private information exchange mechanism for firms to coordinate with each other with potentially adverse effects on consumers. For example, in 2017 the DOJ raided a private meeting among CEOs of several large shipping companies that were involved in multiple alliances as part of an investigation into the potential anticompetitive effects of the firms' new strategic alliances with each other (Saul and Wallis, 2017).
} 
prediction, using multiple measures of public disclosure, I find that firms that enter strategic alliances subsequently reduce their public disclosures of expected future business conditions and specifically reduce disclosure about forecasted demand and production levels.

To sharpen empirical identification and provide more direct evidence that the reduction in public disclosure is due to a reduction in the coordination benefits of disclosure, I conduct three sets of cross-sectional tests. In the first set of tests, I examine whether the reduction in disclosure varies predictably with several proxies for the amount of private communication among alliance partners: (i) whether the alliance is formed among direct competitors, which are more likely to involve the exchange of information that is beneficial for coordination (Teece, 1992; PwC, 2016); (ii) the number of partners, which provide alliance partners with a broader range of information about more firms; (iii) whether the alliance is an equity-based joint venture, which entails stronger contractual ties and the exchange of more detailed financial information (e.g., Kogut, 1988; Gulati and Singh, 1998; Anderson, Christ, Dekker, and Sedatole, 2014); and (iv) whether the alliance involves research and development (R\&D) or manufacturing activities, which require more frequent and detailed private communication relative to other types of alliances (e.g., Anand and Khanna, 2000; Robinson and Stuart, 2007). Using each of these measures of the degree of private communication, I find evidence of a greater reduction in public disclosure when there is more extensive private communication among alliance partners.

In the second set of tests, I examine settings where private communication is limited. In particular, I examine (i) licensing alliances, which involve the exchange of proprietary technology but are less likely to involve frequent information exchange (e.g., 
Anand and Khanna, 2000), and (ii) alliance terminations, which sever firms' private communication channels with their partners. I expect the negative association between strategic alliances and voluntary disclosure to be weaker for firms entering into licensing alliances, and I expect firms that terminate their alliance relationships to subsequently increase their voluntary disclosures. I find that the reduction in public disclosure is unchanged for firms entering licensing alliances and that firms that terminate their alliance relationships subsequently increase their voluntary disclosures.

In the third set of tests, I examine settings with lower a priori coordination benefits and expect a weaker relation between private communication and firms' public disclosure. Theory suggests that the coordination benefits of public disclosure are smallest in highly competitive industries, as firms in more competitive industries benefit more from withholding information from their competitors (Clinch and Verrecchia, 1997; Bertomeu and Liang, 2015). ${ }^{5}$ Based on this intuition, I predict and find evidence that the relation between private communication and firms' public disclosure is weaker among strategic alliances in more competitive industries.

Finally, to help mitigate concerns about omitted variables that may jointly affect both firms' decision to form an alliance and their public disclosure, I use a quasi-natural experiment to examine the effect of a plausibly exogenous shock to firms' incentives to form strategic alliances on their public disclosures. This analysis is based on the staggered adoption of combined reporting rules across different states at different times. Combined

\footnotetext{
${ }^{5}$ For instance, in the context of Clinch and Verrecchia (1997), if a firm in a more competitive industry discloses information that reveals stronger than expected demand, it is more likely to induce its competitors to cut prices in the current period.
} 
reporting rules increase the benefits of implementing investments through strategic alliances by reducing firms' ability to use subsidiaries to shift income across states for tax benefits (e.g., Bodnaruk, Massa, and Simonov, 2013; Li, Qiu, and Wang, 2018). Consistent with prior corporate finance studies, I find that firms that become subject to combined reporting are more likely to form strategic alliances, and in turn, reduce their public disclosures about expected future business conditions, as well as forecasted demand and production levels.

My evidence from multiple sets of complementary tests consistently suggests that firms that privately communicate with each other through strategic alliances reduce their public disclosures that facilitate coordination. Although this evidence is largely indirect that the reduction in public disclosure after establishing a private communication channel is consistent with a reduction in the coordination benefits of public disclosure, other forces could also be responsible for such a reduction in disclosure in my setting. In particular, standard models of voluntary disclosure (e.g., Dye, 1985; Jung and Kwon, 1986; Verrecchia, 1990) suggest four general economic forces that lead to a reduction in voluntary disclosure: (i) an increase in bad news, (ii) an increase in proprietary costs, (iii) a decrease in managers' private information, and (iv) a decrease in investors' uncertainty about the firm. To explain my collective results, these forces would need to systematically vary with (i) firms' strategic alliance activity, (ii) the attributes of their strategic alliances, (iii) product market competition, and (iv) the staggered adoption of combined reporting rules.

I conduct a number of additional analyses designed to mitigate concerns about these forces in my setting. First, I find that strategic alliance announcements are, on average, 
interpreted by equity investors as good news, as evidenced by the positive market reaction to their announcement. Second, with regard to an increase in proprietary costs, I find that firms that enter strategic alliances subsequently reduce their disclosures that are likely to be proprietary and non-proprietary in nature alike. Moreover, my findings are concentrated in industries that are typically considered to have relatively low proprietary costs (e.g., industries with fewer competitors). Third, with regard to a decrease in managers' private information, I find no evidence of a relation between alliance activity and management forecast accuracy, but I do find a strong positive relation between alliance activity and managers' insider trading activity, which, if anything, is consistent with an increase in their private information. Finally, with regard to a decrease in investors' uncertainty, I find a strong positive relation between alliance activity and participants' bid-ask spreads, which is consistent with higher, rather than lower, investor uncertainty. Collectively, these findings are inconsistent with strategic alliances resulting in more bad news, higher proprietary costs, or a reduction in managers' private information or investors' uncertainty.

While much of the prior disclosure literature focuses on the monitoring and valuation roles of public disclosure, my results highlight and shed new light on another important role for public disclosure: namely facilitating coordination among competitors. Only a handful of empirical studies—all of which are recent—examine the role of public disclosure as a coordination mechanism. For example, Bertomeu, Evans, Feng, and Tseng (2015) examine how automobile manufacturers exchange production information through trade associations when engaged in tacit collusion to fix prices. Bloomfield (2018) examines whether competitors use their public compensation disclosures to credibly signal their product market strategies (i.e., aggressive versus accommodating). Finally, Bourveau, 
She, and Žaldokas (2018) examine whether U.S. firms publicly disclose more detailed information about their customers and products following the enactment of foreign antitrust laws. My study contributes to this emerging stream of literature by using strategic alliances as a powerful research setting that entails a large, heterogeneous set of firms that unambiguously establish a legal private communication channels with their competitors to examine how this private communication channel affects their public disclosures.

This paper proceeds as follows. Section 2 provides theoretical and institutional motivation for my empirical predictions. Section 3 describes my sample and measurement choices. Section 4 describes my research design, presents results, and provides a discussion of potential alternative explanations. Section 5 provides concluding remarks.

\section{Background and Empirical Predictions}

\subsection{Background on strategic alliances}

Strategic alliances are a mode of organizing economic activity whereby two or more partners pool certain property- and strategic-decision rights while simultaneously maintaining their distinct ownership and control over other assets, thereby necessitating alliance-specific mechanisms to coordinate their joint activities (Gibbons and Roberts, 2013, p. 1066). Several influential studies define a strategic alliance—often referred to as a "hybrid" organization in the economics literature (Ménard, 2004) —as any voluntary cooperative arrangement among firms that involves the exchange or co-development of products, technologies, or services (Gulati and Singh, 1998; Teece, 1992). For example, in joint ventures — which are one of the most common forms of strategic alliances-firms mutually commit resources and form a separate, jointly owned and controlled legal entity 
to pursue a project, with the profits of the venture typically accruing proportionally to the partners according to their equity stake in the enterprise.

These joint investments characterize business relationships that lie outside of the traditional boundaries of the firm and can be either vertical or horizontal (i.e., between firms and their suppliers or competitors, respectively). Moreover, strategic alliances take a variety of forms including joint ventures, production alliances, franchises, R\&D expense sharing agreements, group purchasing organizations, and more (Ménard, 2004). The three key features of strategic alliances that distinguish them from other forms of economic organization (e.g., internally integrated firms) are (i) the pooling and joint control of resources across firm boundaries, (ii) contracting with partners, and, crucial for my study, (iii) simultaneous competition among the alliance participants' separate business activities (Teece, 1992; Ménard, 2004, p. 351).

The first distinguishing feature of strategic alliances-i.e., the pooling of resources - allows firms to coordinate and cooperate on joint investment decisions pertaining to assets that are worth more if jointly utilized. Delegating tasks across firm boundaries gives rise to a variety of coordination costs for firms involved in strategic alliances, such as developing and maintaining governance structures that minimize opportunistic behavior by strategic alliance partners, as well as ensuring robust inter-firm communication that facilitates collective decision-making.

The second distinguishing feature of strategic alliances-i.e., contracting with partners - is that the members use a variety of formal and informal contracting mechanisms to govern the relationship. For instance, joint ventures require the collaborating firms to form a separate, jointly owned and controlled legal entity. Other forms of strategic 
alliances, such as R\&D expense sharing agreements, often rely less on "complete" (i.e., detailed and exhaustive) contracts and more on relational contracts that are "self-enforced" (or disciplined) by the potential for future profitable business interactions with partners that may be forfeited if one party misbehaves. Economic theory suggests that less formal relational contracts are particularly important for sustaining strategic alliances since they provide a relatively simple yet highly effective way to align alliance partners' interests (Baker, Gibbons, and Murphy, 2008).

The third feature of strategic alliances that distinguishes them from other forms of economic organization-i.e., simultaneous competition among the alliance participants' separate business activities - arises because alliance participants often simultaneously compete in product and labor markets, which introduces countervailing incentives for participants to behave opportunistically at the expense of their partners (Arslan, 2017). Moreover, even alliances among firms that are not necessarily direct competitors-e.g., strategic alliances between firms and their suppliers - can still involve competition. For example, several management studies show that suppliers in many of these "vertical" alliances are more likely to enter their business partners' markets after forming strategic alliances due to "information spillovers" from the information exchanged during alliance relationships (e.g., Jensen and Meckling, 1992; Inkpen and Beamish, 1997; Simonin, 1999; Kale, Singh, and Perlmutter, 2000; Gomes-Casseres, Hagedoorn, and Jaffe, 2006). Information exchanged through private communication represents an important byproduct of strategic alliances. Theory suggests that efficient information exchange is crucial for the formation and success of strategic alliances. For instance, Williamson (1975, p. 31) argues that information asymmetry among partners coupled with their propensity to 
behave opportunistically poses the most severe problem to strategic alliance partners. This threat gives rise to the need for business partners to transparently share information with each other about their alliance and non-alliance activities. Consistent with these arguments, several management studies find that strategic alliances with more effective information exchange policies-e.g., regularly scheduled meetings among senior managers of participating firms, co-location of employees, the right to examine and audit all relevant records and transactions - tend to last longer and are less prone to opportunistic behavior by business partners (e.g., Parkhe, 1993; Thomas and Trevino, 1993; Reuer and Koza, 2000). For example, Parkhe (1993) finds that the most common contractual safeguards in strategic alliance contracts include provisions for timely and accurate communication of information, such as (i) periodic written reports of all relevant transactions, (ii) prompt written notice of any departures from the agreement, and (iii) the right to examine and audit all relevant records through a firm of Certified Public Accountants. ${ }^{6}$ Thus, an important byproduct of strategic alliances is that they establish a credible private communication channel among firms.

Private communication among competitors regarding certain information-e.g., prices, quantities, inventory capacity, etc.- - is likely to draw scrutiny from competition regulators. However, private communications among firms in the context of strategic alliances and joint ventures is generally less likely to conflict with antitrust regulations, "as

\footnotetext{
${ }^{6}$ Furthermore, several managerial accounting studies provide additional evidence that management control systems in strategic alliances are explicitly designed to facilitate the transparent sharing of information between participating firms-e.g., internal reports of financial and non-financial information about participating firms' alliance and non-alliance activities (see, e.g., Anderson and Dekker, 2014; Anderson, Christ, Dekker, and Sedatole, 2014, 2015).
} 
the private disclosure of price information may be commercially justifiable between $[\ldots]$ joint venture participants" (OECD, 2010, p. 108). Highlighting the degree of private communication among firms that strategic alliances facilitate, anecdotal evidence from my extensive conversations with strategic alliance consultants and lawyers indicates that senior management (e.g., CEOs) of strategic alliance partners do, in fact, tend to meet frequently, even if the strategic alliance's operations account for only a small portion of the firm's total operations (e.g., Saul and Wallis, 2017). While anecdotal, this evidence provides further corroboration for the notion that strategic alliances facilitate information exchange among participating firms beyond the scope of the strategic alliance activity.

\subsection{Empirical predictions: strategic alliance formation and public disclosure}

I argue that strategic alliances provide a private channel for credible private information exchange between competitors that reduces the coordination benefits of public disclosure. Theory predicts that it is often in firms' best interest to disclose information about expected future business conditions in order to coordinate their production and pricing decisions (e.g., Fried, 1984; Clinch and Verrecchia, 1997; Bertomeu and Liang, 2015; Arya and Mittendorf, 2016). For example, Fried (1984, p. 376) finds that, by learning about competitors' production decisions through public disclosures, firms can adjust their own production to increase their collective profits (e.g., by avoiding over- or underproduction), and that firms are "better off disclosing even if the competition does not reciprocate."

Clinch and Verrecchia (1997) also study the relation between voluntary disclosure and the degree of coordination between competitors. They find that it can be advantageous for firms to publicly disclose their private information about expected demand in order to 
coordinate production decisions with their rivals. For instance, a firm might publicly disclose that product demand is weaker than expected to encourage its competitors to restrain their own output. Bertomeu and Liang (2015) find a similar result for firms coordinating their pricing strategies and show that public disclosure can be used strategically to sustain oligopolistic rents. In particular, by publicly disclosing information to its competitor, a firm can credibly signal its strategy, and its competitor can better respond in its own pricing and quantity decisions. The disclosing firm anticipates its competitor's response and takes this into account when deciding whether to disclose in the first place - thus there are product market benefits from disclosure. In the context of these models, the coordination benefits of disclosure can be viewed as the opposite of the "proprietary costs" of disclosure: disclosure conveys direct, competitive benefits.

Importantly, the coordination role of public disclosure is predicated on the notion that competing firms cannot credibly exchange information privately. For example, Gigler (1994, p. 229) and Reis and Stocken (2007, pp. 562-3) explain how competing firms' inability to communicate privately is what makes public disclosures a potentially valuable coordination mechanism. However, if firms can credibly exchange information privately, then public disclosure becomes redundant and loses its value as a coordination mechanism. Therefore, allowing for private communication between competitors reduces-and, in the limit, eliminates - the usefulness of public disclosure as a coordination mechanism. To the extent that coordination shapes firms' public disclosures, developing alternative channels to exchange information privately with competitors through strategic alliances should reduce the coordination benefits of public disclosure. Therefore, I predict that strategic alliance participation is associated with a decrease in voluntary disclosure. 
If, on the other hand, the coordination role of disclosure is not a first-order concern for firms' disclosure decisions, I would not expect to observe substitution between private communication among competitors and public disclosure. In the absence of coordination, the valuation role for public disclosure suggests that an increase in managers' private information leads to increased disclosure (see, e.g., Bushee, Keusch, and Kim, 2019). The intuition is that more private information enables the manager to provide more accurate forecasts, which are rewarded by the capital market. Thus, in the absence of a coordinating role of disclosure, I expect strategic alliances to increase managers' private information and, in turn, increase disclosure (e.g., Verrecchia, 1990).

\section{Sample Construction and Descriptive Statistics}

\subsection{Sample construction and strategic alliance characteristics}

I obtain data on strategic alliance activity from 1994 through 2014 from Securities Data Corporation (SDC) Platinum's Alliances and Joint Ventures database, which tracks information on 116,776 unique strategic alliances entered into over this period. ${ }^{7}$ I obtain information on strategic alliances for (i) the start dates of the strategic alliance, (ii) the participants involved in each alliance, (iii) deal characteristics (e.g., whether the strategic alliance involves an equity-based joint venture that forms a separate legal entity), and (iv)

\footnotetext{
${ }^{7}$ Thomson Reuters' SDC Platinum Alliances and Joint Ventures database collects information about strategic alliances between firms from regulatory filings, press releases, and any other publicly available source. Thomson Reuters also maintains relationships with investment banks and law firms that are involved in these corporate deals and submit information to Thomson Reuters. Since public firms are required to disclose these material definitive agreements to shareholders (e.g., via an 8-K), SDC's coverage of strategic alliances includes all of these business arrangements that public firms enter into. Furthermore, Thomson Reuters only collects information on "income-generating" strategic alliances and joint ventures, thereby excluding other types of business collaborations between firms that are not entered into with the purpose of either generating revenues or reducing costs.
} 
the primary scope of the strategic alliance's business activity (e.g., whether the alliance agreement primarily involves manufacturing or R\&D activities). ${ }^{8}$ I merge the SDC data with the universe of firms covered by Compustat and CRSP, resulting in a final sample of 115,912 unique firm-year observations, with 17,056 unique firm-years in which a firm enters at least one strategic alliance.

Consistent with prior management and corporate finance literature on strategic alliances, I measure firms' strategic alliance activity using the natural logarithm of the number of new strategic alliances entered into each year, StrategicAlliance (e.g., Seru, 2014; Bodnaruk, Massa, and Simonov, 2013; Fich, Starks, and Yore, 2014). In particular, I examine new alliances entered into during each year because private communication between strategic alliance partners tends to be greatest at the beginning of the relationship (e.g., from due diligence activities, etc.), and I take the natural logarithm of the number of new strategic alliances entered into each year due to the skewed nature of the data. All variables are defined in Appendix A.

Figure 1 plots strategic alliance activity over time. Panel A shows that the number of new strategic alliances announced each year ranges from a low of 1,530 during the peak of the global financial crisis in 2010 to a high of 10,539 in 2000. Panel B shows that equitybased joint ventures comprise a substantial component of overall strategic alliances. Panel B also shows that much of the increase in strategic alliance activity around 2000 was due

\footnotetext{
${ }^{8}$ Since SDC Platinum's Alliances and Joint Ventures data is not machine-readable at the individual firm level, I develop a Python script to extract individual firm-level details from each alliance in the database and match them to the universe of firms covered by Compustat and CRSP on CUSIP.
} 
to non-equity strategic alliances that do not involve a formal joint venture agreement between firms.

\section{Figure 1. New Strategic Alliances Announcements per Year}

This figure plots the number of new strategic alliances announced per year. Panel A presents the total number of new strategic alliances announced each year. Panel B presents the total number of new joint ventures and non-joint venture strategic alliances (i.e., "Contractual Strategic Alliances") announcements separately. Sample consists of 145,374 new strategic alliances appearing on Thomson Reuters' Securities Data Corporation (SDC) Platinum Alliances and Joint Ventures Database from 1990 through 2016.

Panel A. All Strategic Alliances

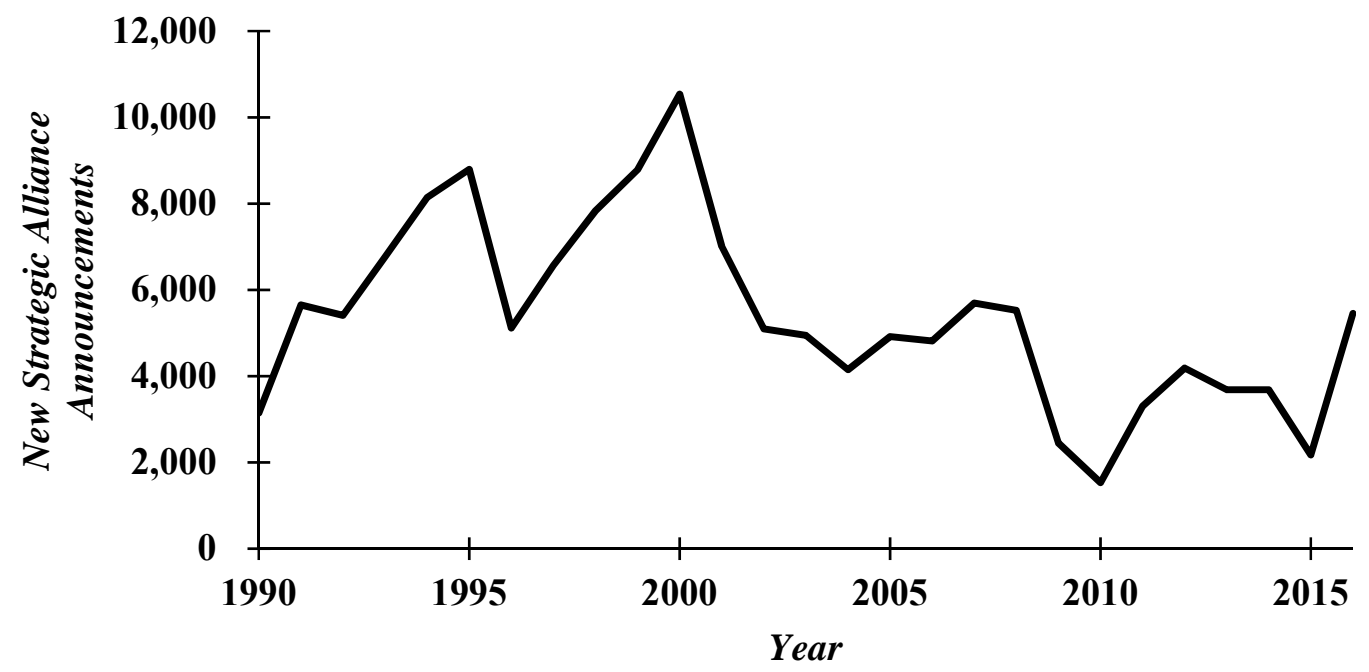

Panel B. Strategic Alliance Activity by Alliance Type

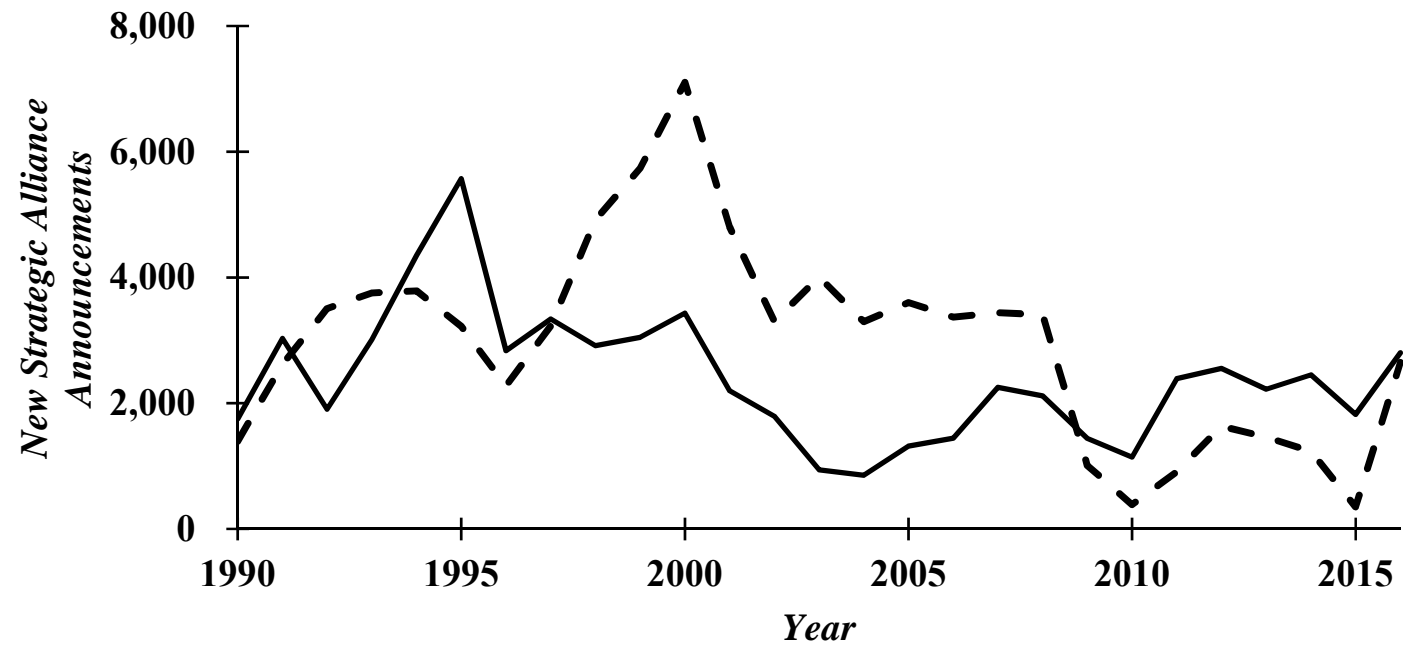

Joint Ventures _ - Contractual Strategic Alliances 
Table 1 contains descriptive statistics for my broader sample of alliances covered by SDC over my sample period. Panel A presents strategic alliance-level Fama-French 12 industry distribution and the characteristics of all 116,776 strategic alliances covered by SDC Platinum's Alliances and Joint Ventures database. Strategic alliances occur across all industries but are most common in business equipment, financial, and retail industries. Panel B presents descriptive statistics for voluntarily disclosed strategic alliance characteristics for this sample. The average strategic alliance is expected to last for roughly ten years (mean ExpectedLength $=9.53$ ). The average total expected cost of strategic alliances is $\$ 400$ million (mean EstAllianceCost $=399.11$ ), and the average estimated joint venture capitalization (i.e., assets minus debt) is approximately $\$ 150$ million (mean EstJointVentureCost $=148.90)$. Appendix B provides excerpts from several strategic alliance announcements for the most common types of strategic alliances in my sample, and illustrates the considerable heterogeneity in the types of strategic alliances, the scope of alliance operations, and the types of alliance partners. 


\section{Table 1. Strategic Alliance Descriptive Statistics}

This table presents the distribution of select variables from Securities Data Corporation (SDC) Platinum's Alliances and Joint Ventures database. Panel A presents Fama-French 12 industry classifications of 116,776 new strategic alliances announced over my sample period. Panel B presents strategic alliance-level characteristics that are selectively disclosed by firms and covered by SDC Platinum. ExpectedLength is the original expected length of the alliance in years. EstAllianceCost is the estimated cost (in \$ millions) that the alliance members expect to spend on the alliance. EstJointVentureCost is the estimated capitalization (assets minus debt, in \$ millions) of the joint venture. Sample period is 1994 through 2014 for all strategic alliances covered by SDC.

\section{Panel A. Strategic Alliance Industry Distribution}

\begin{tabular}{lcc}
\hline \hline & $\begin{array}{c}\text { Number of } \\
\text { Strategic } \\
\text { Alliances }\end{array}$ & $\begin{array}{c}\% \text { of Strategic } \\
\text { Alliances }\end{array}$ \\
Fama-French 12 Industry Groups & 28,035 & $24.0 \%$ \\
\hline Business equipment & 3,213 & $2.8 \%$ \\
Chemicals and allied products & 3,561 & $3.1 \%$ \\
Consumer durables & 3,971 & $3.4 \%$ \\
Oil, gas, and coal extraction products & 4,735 & $4.1 \%$ \\
Healthcare, medical equipment, and drugs & 7,686 & $6.6 \%$ \\
Manufacturing & 14,275 & $12.2 \%$ \\
Financial firms & 3,950 & $3.4 \%$ \\
Consumer nondurables & 29,118 & $24.9 \%$ \\
Other & 10,729 & $9.2 \%$ \\
Wholesale, retail, and some services & 4,999 & $4.3 \%$ \\
Telephone and television transmission & 2,504 & $2.1 \%$ \\
Utilities & 116,776 & $100.00 \%$ \\
& \multicolumn{2}{c}{} \\
\hline \hline
\end{tabular}

\section{Panel B. Strategic Alliance Characteristics}

\begin{tabular}{|c|c|c|c|c|c|c|}
\hline Variable & $\mathrm{N}$ & Mean & Std & 25 th & Median & 75 th \\
\hline \multicolumn{7}{|c|}{ Strategic Alliance Characteristics with Limited Disclosure } \\
\hline ExpectedLength & 4,075 & 9.53 & 11.59 & 3.00 & 5.00 & 10.00 \\
\hline EstAllianceCost & 8,223 & 399.11 & $1,697.24$ & 9.50 & 41.30 & 200.00 \\
\hline EstJointVentureCost & 5,531 & 148.90 & $1,705.29$ & 1.90 & 7.70 & 30.00 \\
\hline
\end{tabular}

\subsection{Descriptive statistics}

Table 2 presents descriptive statistics for the variables in my primary analyses.

Panel A provides descriptive statistics for my pooled sample of all public firms at the intersection of the CRSP and Compustat universe, and Panel B provides descriptive statistics for the key variables used in my cross-sectional analysis that examines only firms that form strategic alliances. Consistent with prior strategic alliance studies (e.g., 
Bodnaruk, Massa, and Simonov, 2013), approximately 15\% of all firm-years in my pooled sample involve the formation of at least one new strategic alliance (mean StrategicAllianceInd $=0.15)$.

\section{Table 2. Descriptive Statistics}

This table presents the distribution of key variables used in my analysis using all public firm-years available in CRSP and Compustat. All variables are as defined in Appendix A. Panel A presents descriptive statistics for my pooled sample of all firm-years, and Panel B presents descriptive statistics for key variables used in my cross-sectional tests restricted to only firm-years where the firm forms at least one new strategic alliance as well as stock return and trading volume descriptive statistics for all announced strategic alliances that are included in my sample. Sample period is 1994 through 2014. All continuous variables are winsorized at 1\% and 99\% levels.

\section{Panel A. Pooled Sample}

\begin{tabular}{|c|c|c|c|c|c|c|}
\hline Variable & $\mathrm{N}$ & Mean & Std & 25 th & Median & 75th \\
\hline \multicolumn{7}{|l|}{ Strategic Alliance } \\
\hline \multicolumn{7}{|l|}{ Characteristics } \\
\hline$\overline{\text { StrategicAlliance }}$ & 115,912 & 0.18 & 0.48 & 0.00 & 0.00 & 0.00 \\
\hline StrategicAllianceInd & 115,912 & 0.15 & 0.35 & 0.00 & 0.00 & 0.00 \\
\hline \multicolumn{7}{|l|}{ Controls } \\
\hline Size & 115,912 & 5.66 & 2.21 & 4.03 & 5.57 & 7.17 \\
\hline SalesVol & 115,912 & 0.23 & 0.26 & 0.06 & 0.16 & 0.30 \\
\hline$B T M$ & 115,912 & 0.66 & 0.64 & 0.29 & 0.53 & 0.86 \\
\hline Leverage & 115,912 & 0.55 & 0.27 & 0.34 & 0.55 & 0.76 \\
\hline$R O A$ & 115,912 & -0.04 & 0.24 & -0.02 & 0.02 & 0.06 \\
\hline SpecItems & 115,912 & -0.02 & 0.06 & -0.01 & 0.00 & 0.00 \\
\hline Loss & 115,912 & 0.31 & 0.46 & 0.00 & 0.00 & 1.00 \\
\hline Returns & 115,912 & 0.14 & 0.64 & -0.24 & 0.05 & 0.35 \\
\hline IdioVol & 115,912 & 0.12 & 0.09 & 0.06 & 0.10 & 0.16 \\
\hline NumSegments & 115,912 & 2.40 & 1.95 & 1.00 & 2.00 & 3.00 \\
\hline$R \& D$-to-Sales & 115,912 & 0.20 & 1.06 & 0.00 & 0.00 & 0.04 \\
\hline \multicolumn{7}{|c|}{ Public Disclosure Measures } \\
\hline VolDisc & 115,912 & 3.14 & 6.56 & 0.00 & 0.00 & 3.00 \\
\hline CapExDisc & 115,912 & 0.38 & 1.19 & 0.00 & 0.00 & 0.00 \\
\hline SalesDisc & 115,912 & 0.83 & 2.16 & 0.00 & 0.00 & 0.00 \\
\hline ProductionDisc & 115,912 & 2.17 & 1.95 & 0.00 & 2.40 & 3.89 \\
\hline MarketDemandDisc & 115,912 & 0.80 & 1.15 & 0.00 & 0.00 & 1.61 \\
\hline \multicolumn{7}{|l|}{ Competition Measures } \\
\hline$H H I$ & 115,912 & -2.51 & 1.51 & -2.88 & -2.15 & -1.46 \\
\hline Log(NumFirms) & 115,912 & 6.67 & 0.69 & 6.31 & 6.76 & 7.25 \\
\hline MktShareTop 5 & 115,912 & -0.26 & 0.09 & -0.29 & -0.25 & -0.18 \\
\hline
\end{tabular}




\section{Table 2. Descriptive Statistics (cont'd)}

\section{Panel B. Strategic Alliance Sample}

\begin{tabular}{lcccccc}
\hline \hline Variable & $\mathrm{N}$ & Mean & Std & 25th & Median & 75th \\
\hline Strategic Alliance Firm-Year & & & & & & \\
Characteristics & & & & & & \\
NewStrategicAlliances & 17,056 & 4.10 & 9.52 & 1.00 & 2.00 & 4.00 \\
Competitors & 17,056 & 1.82 & 3.85 & 0.00 & 1.00 & 2.00 \\
NParticipants & 17,056 & 2.11 & 0.28 & 2.00 & 2.00 & 2.00 \\
JointVenture & 17,056 & 0.38 & 0.48 & 0.00 & 0.00 & 1.00 \\
HighInfo & 17,056 & 0.36 & 0.48 & 0.00 & 0.00 & 1.00 \\
LowInfo & 17,056 & 0.17 & 0.37 & 0.00 & 0.00 & 0.00 \\
TerminatedAlliances & 17,056 & 0.05 & 0.39 & 0.00 & 0.00 & 0.00 \\
\hline \hline
\end{tabular}

In Panel A of Table 2, the average management forecast frequency (VolDisc) in my sample is 3.14 forecasts per year. My sample firms have an average book-to-market ratio $(B T M)$ of 0.66 , leverage ratio (Leverage) of 0.55 , return-on-assets $(R O A)$ of -0.04 , special items (SpecItems) of -0.02 , idiosyncratic volatility (IdioVol) of 0.12 , and stock returns (Returns) of 0.12 during the previous fiscal year.

Panel B of Table 2 presents descriptive statistics for my sample of unique firmyears where the firm forms at least one new strategic alliance during the fiscal year. In this restricted sample, $38 \%$ entered into at least one formal equity-based joint venture that formed a new legal business entity (mean JointVenture $=0.38$ ), the average alliance contains two participants (mean NParticipants $=2.11$ ), the average firm enters two alliances with direct competitors in the same industry (mean Competitor $=1.82$ ). In total, $36 \%$ of these firms entered at least one strategic alliance where the primary activity of the alliance was to pursue manufacturing, production, or R\&D-related activities (mean HighInfo $=0.36$ ), and $17 \%$ of these firms entered at least one strategic alliance where the primary activity was to license products, services, or technology (mean LowInfo $=0.17$ ). 


\section{Research Design and Results}

In order to triangulate evidence of the relation between strategic alliances and voluntary disclosure, I use multiple measures of voluntary disclosure that theory and institutional features suggest are useful for coordination purposes, and employ three distinct sets of tests. I first examine the relation between firms' strategic alliance activity and voluntary disclosure, using both pooled cross-sectional and within-firm research designs. The advantage of this approach is that it uses a broad sample of firms to compare firms that form strategic alliances to those that do not form strategic alliances.

Next, I examine the subsample of firms that form at least one strategic alliance during the year, and exploit heterogeneity in the degree of private communication between strategic alliance partners based on the economic and contractual characteristics of their new alliances. I also test for cross-sectional differences based on industry characteristics in my pooled tests that examine the relation between strategic alliances and voluntary disclosure for all firms. These tests allow me to compare the moderating effect of industry competition on the relation between public disclosure and strategic alliances for firms that enter into strategic alliances relative to firms that do not form strategic alliances.

Finally, I use the staggered adoption of combined reporting rules in different states at different times as an exogenous shock to the incentives to form strategic alliances. My research designs discussed above take firms' strategic alliance activity as exogenous, and assume that the coordination benefits of private communication are not a first-order determinant — but rather are an incidental by-product — of strategic alliance formation that affects firms' public disclosures. In contrast, this final research design allows me to relax that maintained assumption to assess whether my results continue to hold in a setting that 
involves arguably exogenous variation in firms' strategic alliance activity. Using a generalized difference-in-differences research design, I estimate the change in voluntary disclosure for firms affected by combined reporting rules that increased the incentives to form strategic alliances, relative to unaffected firms.

\subsection{Strategic alliance formation and public disclosure}

\subsubsection{Research design}

In order to test my primary predictions, I examine the relation between firms' public voluntary disclosure behavior and strategic alliance activity while controlling for the known determinants of firms' voluntary disclosure behavior. In particular, I estimate the following model on a pooled sample of all firm-years in my sample:

$$
\text { VolDisc } i, t+1=\alpha+\beta_{1} \text { StrategicAlliance }_{i, t}+\theta \text { Controls }+\varepsilon,
$$

where VolDisc is one of several measures of quantitative (i.e., management capital expenditure or sales forecasts) or qualitative voluntary disclosure about expected production or market demand. I first measure VolDisc using the number of management forecasts (e.g., earnings, revenue, investment, etc.) provided during the subsequent fiscal year. Management forecasts reduce uncertainty for external parties (e.g., investors, competitors) by providing information about the firm's future business conditions. I also disaggregate management forecasts into sales forecasts and investment forecasts (SalesDisc and CapEx forecasts, respectively), since this type of information is particularly useful in reducing competitors' uncertainty about the firm's future production decisions. StrategicAlliance is a continuous measure of a firm's new total strategic alliance activity during the year, following prior corporate finance and management studies (e.g., Bodnaruk, Massa, and Simonov, 2013; Li, Qiu, and Wang, 2018), defined as the natural logarithm of 
one plus the total number of new strategic alliances the firm entered during the fiscal year. ${ }^{9}$ Controls is a vector of the following firm-year level controls: Size, SalesVol, BTM, Leverage, ROA, SpecItems, Loss, Returns, IdioVol, NumSegments, and R\&D-to-Sales (e.g., Ali, Klasa, and Yeung, 2014; Guay, Samuels, and Taylor, 2016).

I also estimate Eq. (1) using multiple qualitative measures of firms' public disclosure topics that are likely relevant for coordination purposes. In particular, I scrape all 8-Ks filed with the SEC for keywords related to firms' production quantities, pricing, and investment plans (ProductionDisc), as well as firms' discussions of expected demand and market conditions (MarketDemandDisc). While these disclosures are not quantitative like my previous measures, prior accounting research shows that word-frequency measures of firms' public disclosures capture qualitative information that quantitative measures of disclosure are unable to (e.g., Henry and Leone, 2015; Loughran and McDonald, 2016). A key advantage of this measurement choice is that the language I use to measure firms' qualitative disclosure topics is consistent with the information that antitrust regulators are primarily concerned with that facilitate coordination between firms (e.g., OECD, 2010; FTC, 2011; NERA, 2014), and is also consistent with economic theory about the types of public disclosures that are most likely to facilitate coordination — namely information about expected investment and production decisions and market demand (e.g., Fried, 1985; Clinch and Verrecchia, 1997; Bertomeu and Liang, 2015; Arya and Mittendorf, 2016). ${ }^{10}$

\footnotetext{
${ }^{9}$ All of my tabulated results are qualitatively similar—i.e., of the same sign and level of significance —using an indicator for whether the firm entered into at least one strategic alliance during the fiscal year, and zero otherwise, to measure StrategicAlliance (e.g., Fich, Starks, and Yore, 2014).

${ }^{10}$ While public voluntary disclosure about expected demand and production is one way that competitors can exchange information to coordinate their actions, firms could also use personal interactions between executives at conferences, discussions in mandatory disclosures (e.g., the MD\&A section of an annual report), or other forms of communication (e.g., conference calls) to publicly exchange information that may
} 
I also augment each model separately with industry and firm fixed effects to control for time-invariant differences across industries and firms, respectively. Industry fixed effects control for time-invariant unobserved differences across industries that affect firms' strategic alliance activity (e.g., firms in more research-intensive industries are inherently more likely to form strategic alliances). Firm fixed effects control for time-invariant firm characteristics that may affect whether firms form strategic alliances. Thus, including firm fixed effects identifies the relation between strategic alliances and disclosure based on within-firm (i.e., time-series) variation in strategic alliance activity. Throughout all of my analyses, I calculate standard errors clustered by firm to allow for autocorrelation in firms' disclosure behavior over time within a given firm.

\subsubsection{Results}

Table 3 presents results from estimating Eq. (1) using my quantitative measures of public disclosure. Across all specifications, for each measure of quantitative disclosure (i.e., VolDisc, CapExDisc, and SalesDisc, respectively), I find a negative relation between StrategicAlliance and public disclosure (StrategicAlliance; coeffs $-1.093,-0.509,-0.294$, $-0.135,-0.224,-0.098 ; t$-stats $-12.32,-7.61,-10.56,-6.19,-16.09,-7.21) .{ }^{11}$ These results

be useful for coordinating their production and pricing decisions. Each of these methods entails different costs and benefits and firms likely simultaneously employ several forms of communication to exchange information in order to coordinate their production and investment activities. In this study, however, I explicitly focus on voluntary disclosure about expected demand and production since economic theory provides clear empirical predictions for how coordination benefits affect firms' voluntary disclosures of information about future expected business conditions, whereas empirical evidence supporting these theories is limited at best.

${ }^{11}$ In order to provide a clear interpretation of the economic magnitude of these results, I re-estimate Eq. (1) after including industry fixed effects - using an indicator for whether the firm formed at least one strategic alliance during the fiscal year (StrategicAllianceInd). In untabulated results, the coefficient on StrategicAllianceInd is -0.935 ( $t$-stat -9.21 ), suggesting that firms that enter into strategic alliances provide one fewer management forecasts during the subsequent year-approximately $15 \%$ of my sample standard deviation of VolDisc - relative to firms that do not form strategic alliances, all else equal. 
suggest that both cross-sectionally and when using the firm as its own control (i.e., including firm fixed effects in columns (2), (4), and (6)), strategic alliances are negatively associated with firms' public voluntary disclosure. Importantly, in columns (3) through (6) I find that these effects are also present using measures of capital expenditure and sales forecasts, which are the types of forecasts that are most likely to be useful for coordination purposes. $^{12}$ Collectively, these results provide consistent evidence that firms that enter strategic alliances subsequently reduce their quantitative public disclosures. ${ }^{13}$

Table 4 presents results from estimating Eq. (1) using textual analysis-based qualitative measures of public disclosure. Across all specifications, for each measure of qualitative public disclosure (i.e., ProductionDisc and MarketDemandDisc, respectively), I find a negative relation between StrategicAlliance and firms' qualitative topic of public disclosure (StrategicAlliance; coeffs $-0.158,-0.098,-0.034,-0.023$; $t$-stats $-5.47,-5.98$, $-2.53,-2.28)$. These results suggest that in both pooled cross-section and within-firm designs, firms' strategic alliance activity is negatively associated with firms' public disclosures about expected future business conditions. ${ }^{14}$ Collectively, these results provide consistent evidence that firms that enter strategic alliances subsequently reduce their quantitative and qualitative public disclosures.

\footnotetext{
${ }^{12}$ All of my results are qualitatively similar - i.e., of the same sign and level of statistical significance —using management forecast indicators to measure VolDisc.

${ }^{13}$ I also investigate the timing of the relation between strategic alliances and public disclosure by examining the relation between voluntary disclosure and firms' large alliance shocks (e.g., Armstrong, Glaeser, Huang, and Taylor, 2018). Results in Table IA1 indicate that firms begin to reduce their voluntary disclosure during the year leading up to the large alliance shock, consistent with private communication during the due diligence process substituting for public disclosure.

${ }^{14}$ For instance, in the cross-section (i.e., models including industry fixed effects), a one standard deviation increase in strategic alliance activity is associated with a $3.5 \%(2.5 \%)$ reduction in discussion about production quantities and investment levels (future business conditions and market demand).
} 


\section{Table 3. Strategic Alliances and Voluntary Disclosure}

This table presents results from regressions of voluntary disclosure on strategic alliance activity. All variables are as defined in Appendix A. Columns (1), (3), and (5) include untabulated Fama-French 12 industry fixed effects. Columns (2), (4), and (6) include untabulated firm fixed effects. Columns (1) and (2) present results using my primary measure of voluntary disclosure (VolDisc). Columns (3) and (4) present results using CapExDisc as an alternative measure of voluntary disclosure and Columns (5) and (6) present results using SalesDisc as an alternative measure of voluntary disclosure. $t$-statistics appear in parentheses and are clustered by firm. ${ }^{*}, * * * *$ indicate statistical significance (two-sided) at the $0.1,0.05$, and 0.01 levels, respectively.

\begin{tabular}{|c|c|c|c|c|c|c|}
\hline \multirow{2}{*}{$\begin{array}{l}\text { Dependent } \\
\text { Variable: } \\
\text { Variable }\end{array}$} & \multicolumn{2}{|c|}{ VolDisc $_{t+1}$} & \multicolumn{2}{|c|}{ SalesDisc $_{t+1}$} & \multicolumn{2}{|c|}{ CapExDisc $_{t+1}$} \\
\hline & (1) & (2) & (3) & (4) & $(5)$ & (6) \\
\hline Alliance & $\begin{array}{l}-1.093 * * * \\
(-12.32)\end{array}$ & $\begin{array}{l}-0.509 * * * \\
(-7.61)\end{array}$ & $\begin{array}{l}-0.294 * * * \\
(-10.56)\end{array}$ & $\begin{array}{l}-0.135 * * * \\
(-6.19)\end{array}$ & $\begin{array}{l}-0.224 * * * \\
(-16.09)\end{array}$ & $\begin{array}{l}-0.098 * * * \\
(-7.21)\end{array}$ \\
\hline \multicolumn{7}{|l|}{ Controls } \\
\hline Size & $\begin{array}{l}1.043^{* * * *} \\
(37.30)\end{array}$ & $\begin{array}{l}1.926^{* * * *} \\
(34.54)\end{array}$ & $\begin{array}{l}0.210^{* * * *} \\
(25.09)\end{array}$ & $\begin{array}{l}0.454 * * * \\
(24.83)\end{array}$ & $\begin{array}{l}0.146^{* * *} \\
(30.15)\end{array}$ & $\begin{array}{l}0.304^{* * * *} \\
(25.22)\end{array}$ \\
\hline SalesVol & $\begin{array}{l}0.550 * * * \\
(3.66)\end{array}$ & $\begin{array}{l}-1.569 * * * \\
(-5.98)\end{array}$ & $\begin{array}{l}0.213^{* * *} \\
(4.24)\end{array}$ & $\begin{array}{l}-0.584 * * * \\
(-6.46)\end{array}$ & $\begin{array}{l}-0.038 \\
(-1.57)\end{array}$ & $\begin{array}{l}-0.190 * * * \\
(-3.87)\end{array}$ \\
\hline BTM & $\begin{array}{l}-0.047 \\
(-1.00)\end{array}$ & $\begin{array}{l}1.097 * * * \\
(22.00)\end{array}$ & $\begin{array}{l}-0.063 * * * \\
(-4.26)\end{array}$ & $\begin{array}{l}0.274 * * * \\
(17.11)\end{array}$ & $\begin{array}{l}0.041^{* * *} \\
(4.41)\end{array}$ & $\begin{array}{l}0.207^{* * *} \\
(18.17)\end{array}$ \\
\hline Leverage & $\begin{array}{l}-0.288^{*} \\
(-1.74)\end{array}$ & $\begin{array}{l}3.722 * * * \\
(17.20)\end{array}$ & $\begin{array}{l}-0.298 * * * \\
(-5.52)\end{array}$ & $\begin{array}{l}1.015^{* * *} \\
(14.08)\end{array}$ & $\begin{array}{l}0.190 * * * \\
(6.64)\end{array}$ & $\begin{array}{l}0.610^{* * *} \\
(13.69)\end{array}$ \\
\hline$R O A$ & $\begin{array}{l}0.718 * * * \\
(5.64)\end{array}$ & $\begin{array}{l}-0.259 * \\
(-1.67)\end{array}$ & $\begin{array}{l}0.351 * * * \\
(7.76)\end{array}$ & $\begin{array}{r}0.075 \\
(1.30)\end{array}$ & $\begin{array}{c}0.036 \\
(1.62)\end{array}$ & $\begin{array}{l}-0.103 * * * \\
(-3.88)\end{array}$ \\
\hline SpecItems & $\begin{array}{l}-2.248 * * * \\
(-6.49)\end{array}$ & $\begin{array}{r}0.490 \\
(1.52)\end{array}$ & $\begin{array}{l}-0.716^{* * *} \\
(-5.65)\end{array}$ & $\begin{array}{c}0.097 \\
(0.81)\end{array}$ & $\begin{array}{l}-0.294 * * * \\
(-4.82)\end{array}$ & $\begin{array}{l}-0.071 \\
(-1.20)\end{array}$ \\
\hline Loss & $\begin{array}{l}0.167 * * \\
(2.28)\end{array}$ & $\begin{array}{l}-0.071 \\
(-1.32)\end{array}$ & $\begin{array}{l}0.143^{* * * *} \\
(5.72)\end{array}$ & $\begin{array}{c}0.012 \\
(0.62)\end{array}$ & $\begin{array}{l}0.020^{*} \\
(1.71)\end{array}$ & $\begin{array}{l}0.051 * * * \\
(4.67)\end{array}$ \\
\hline Returns & $\begin{array}{l}-0.144 * * * \\
(-5.06)\end{array}$ & $\begin{array}{l}-0.255^{* * *} \\
(-9.28)\end{array}$ & $\begin{array}{c}0.016 \\
(1.50)\end{array}$ & $\begin{array}{l}-0.020 * \\
(-1.96)\end{array}$ & $\begin{array}{l}-0.032 * * * \\
(-6.38)\end{array}$ & $\begin{array}{l}-0.061^{* * *} \\
(-11.25)\end{array}$ \\
\hline IdioVol & $\begin{array}{l}-4.406 * * * \\
(-14.62)\end{array}$ & $\begin{array}{l}-4.899 * * * \\
(-17.48)\end{array}$ & $\begin{array}{l}-1.688^{* * *} \\
(-15.66)\end{array}$ & $\begin{array}{l}-2.050 * * * \\
(-20.03)\end{array}$ & $\begin{array}{l}-0.492 * * * \\
(-10.01)\end{array}$ & $\begin{array}{l}-0.364 * * * \\
(-7.25)\end{array}$ \\
\hline NumSegments & $\begin{array}{l}0.120 * * * \\
(3.87)\end{array}$ & $\begin{array}{l}0.387 * * * \\
(12.05)\end{array}$ & $\begin{array}{l}0.079 * * * \\
(7.59)\end{array}$ & $\begin{array}{l}0.145^{* * *} \\
(12.87)\end{array}$ & $\begin{array}{l}0.016^{* * *} \\
(2.68)\end{array}$ & $\begin{array}{l}0.075^{* * *} \\
(10.04)\end{array}$ \\
\hline$R \& D$-to-Sales & $\begin{array}{l}-0.271 * * * \\
(-12.78)\end{array}$ & $\begin{array}{l}-0.143 * * * \\
(-5.00)\end{array}$ & $\begin{array}{l}-0.088^{* * *} \\
(-11.68)\end{array}$ & $\begin{array}{l}-0.077 * * * \\
(-6.34)\end{array}$ & $\begin{array}{l}-0.010^{* * *} \\
(-3.51)\end{array}$ & $\begin{array}{c}0.002 \\
(0.50)\end{array}$ \\
\hline Fixed Effects & industry & firm & industry & firm & industry & firm \\
\hline $\mathrm{F}$ & 207.7 & 142.0 & 137.4 & 99.03 & 121.0 & 74.99 \\
\hline $\mathrm{N}$ & 115,912 & 115,912 & 115,912 & 115,912 & 115,912 & 115,912 \\
\hline
\end{tabular}




\section{Table 4. Strategic Alliances and Topic of Public Disclosure}

This table presents results from regressions of two measures of the topic of 8-K disclosures by firms on strategic alliance activity. Columns (1) and (2) present results using firms' discussions of expected production and investment (ProductionDisc) to measure topic of public disclosure. Columns (3) and (4) present results using firms' discussions of expected future business conditions (MarketDemandDisc) to measure topic of public disclosure. All variables are as defined in Appendix A. Columns (1) and (3) of each panel include untabulated Fama-French 12 industry fixed effects. Columns (2) and (4) of each panel include untabulated firm fixed effects. $t$-statistics appear in parentheses and are clustered by firm. $*, * *, * * *$ indicate statistical significance (two-sided) at the $0.1,0.05$, and 0.01 levels, respectively.

\begin{tabular}{|c|c|c|c|c|}
\hline \multirow{2}{*}{$\begin{array}{l}\text { Dependent Variable: } \\
\text { Variable }\end{array}$} & \multicolumn{2}{|c|}{ ProductionDisc $_{t+1}$} & \multicolumn{2}{|c|}{ MarketDemandDisc $_{t+1}$} \\
\hline & (1) & (2) & (3) & (4) \\
\hline StrategicAlliance & $\begin{array}{l}-0.158^{* * *} \\
(-5.47)\end{array}$ & $\begin{array}{l}-0.098 * * * \\
(-5.98)\end{array}$ & $\begin{array}{l}-0.034^{* *} \\
(-2.53)\end{array}$ & $\begin{array}{l}-0.023^{* *} \\
(-2.28)\end{array}$ \\
\hline \multicolumn{5}{|l|}{ Controls } \\
\hline Size & $\begin{array}{l}0.258^{* * *} \\
(30.53)\end{array}$ & $\begin{array}{l}0.394 * * * \\
(33.19)\end{array}$ & $\begin{array}{l}0.077^{* * *} \\
(19.01)\end{array}$ & $\begin{array}{l}0.098 * * * \\
(13.66)\end{array}$ \\
\hline SalesVol & $\begin{array}{l}0.373^{* * *} \\
(8.99)\end{array}$ & $\begin{array}{l}-0.028 \\
(-0.43)\end{array}$ & $\begin{array}{l}0.164 * * * \\
(7.07)\end{array}$ & $\begin{array}{l}0.107^{* * *} \\
(2.83)\end{array}$ \\
\hline BTM & $\begin{array}{l}0.034 * \\
(1.91)\end{array}$ & $\begin{array}{l}0.278^{* * * *} \\
(17.32)\end{array}$ & $\begin{array}{l}0.030 * * * \\
(3.24)\end{array}$ & $\begin{array}{l}0.056^{* * * *} \\
(5.62)\end{array}$ \\
\hline Leverage & $\begin{array}{l}0.387^{* * * *} \\
(8.08)\end{array}$ & $\begin{array}{l}0.897^{* * *} \\
(16.36)\end{array}$ & $\begin{array}{c}0.368^{* * *} \\
(15.04)\end{array}$ & $\begin{array}{l}0.174 * * * \\
(5.45)\end{array}$ \\
\hline$R O A$ & $\begin{array}{l}-0.513 * * * \\
(-9.64)\end{array}$ & $\begin{array}{l}-0.552^{* * *} \\
(-9.84)\end{array}$ & $\begin{array}{l}-0.137 * * * \\
(-4.98)\end{array}$ & $\begin{array}{l}-0.200 * * * \\
(-6.26)\end{array}$ \\
\hline SpecItems & $\begin{array}{r}0.031 \\
(0.24)\end{array}$ & $\begin{array}{l}0.651^{* * *} \\
(5.67)\end{array}$ & $\begin{array}{l}-0.128^{*} \\
(-1.77)\end{array}$ & $\begin{array}{l}0.255^{* * *} \\
(3.45)\end{array}$ \\
\hline Loss & $\begin{array}{l}0.373^{* * * *} \\
(17.20)\end{array}$ & $\begin{array}{l}0.208^{* * * *} \\
(11.87)\end{array}$ & $\begin{array}{l}0.100^{* * * *} \\
(8.23)\end{array}$ & $\begin{array}{l}0.085^{* * * *} \\
(7.61)\end{array}$ \\
\hline Returns & $\begin{array}{l}0.051^{* * *} \\
(5.15)\end{array}$ & $\begin{array}{l}0.025^{* * *} \\
(2.86)\end{array}$ & $\begin{array}{l}0.029^{* * * *} \\
(4.79)\end{array}$ & $\begin{array}{l}0.016^{* * *} \\
(2.77)\end{array}$ \\
\hline IdioVol & $\begin{array}{c}0.022 \\
(0.21)\end{array}$ & $\begin{array}{l}-0.082 \\
(-0.92)\end{array}$ & $\begin{array}{l}0.442 * * * \\
(7.60)\end{array}$ & $\begin{array}{l}0.419 * * * \\
(7.49)\end{array}$ \\
\hline NumSegments & $\begin{array}{l}-0.050^{* * *} \\
(-5.93)\end{array}$ & $\begin{array}{l}0.064^{* * *} \\
(8.42)\end{array}$ & $\begin{array}{l}-0.017 * * * \\
(-4.19)\end{array}$ & $\begin{array}{l}0.019^{* * *} \\
(4.31)\end{array}$ \\
\hline$R \& D$-to-Sales & $\begin{array}{l}-0.002 \\
(-0.21) \\
\end{array}$ & $\begin{array}{c}-0.014 \\
(-1.34) \\
\end{array}$ & $\begin{array}{l}-0.028^{* * *} \\
(-6.44)\end{array}$ & $\begin{array}{l}-0.008 \\
(-1.49)\end{array}$ \\
\hline Fixed Effects & industry & firm & industry & firm \\
\hline $\mathrm{F}$ & 164.5 & 146.3 & 77.34 & 37.99 \\
\hline $\mathrm{N}$ & 115,912 & 115,912 & 115,912 & 115,912 \\
\hline
\end{tabular}




\subsection{The degree of private communication in strategic alliances}

\subsubsection{Research design}

I next focus on strategic alliances between firms that likely have reasons to coordinate in their separate (i.e., non-alliance) activities and contrast these with strategic alliances between firms that are less likely to have reasons to coordinate. Strategic alliances that require partners to share information that is more useful for coordinating their business activities should lead to a greater reduction in coordination benefits to public disclosure for these firms. Therefore, I expect the reduction in voluntary disclosure to be more pronounced for firms that form alliances that involve greater private communication of information that is useful for coordination. To test this prediction, I restrict my analysis to the subsample of firms-years that form at least one strategic alliance during the year and re-estimate Eq. (1) after interacting StrategicAlliance with measures of strategic alliance deal characteristics that prior management studies (e.g., Anand and Khanna, 2000) use to capture the degree of information exchange between alliance partners in the following specification:

$$
\begin{aligned}
\text { VolDisc } i, t+1+\alpha & +\beta_{1} \text { PrivateInfo }_{i, t} \times \text { StrategicAlliance }_{i, t}+\beta_{2} \text { PrivateInfo }_{i, t} \\
& +\beta_{3} \text { StrategicAlliance }_{i, t}+\theta \text { Controls }+\varepsilon .
\end{aligned}
$$

I measure PrivateInfo in Eq. (2) using four distinct variables that capture the degree of private information exchange in strategic alliances, and expect a more negative association between strategic alliances and voluntary disclosure for firms that enter into alliances with these characteristics (i.e., $\beta_{1}<0$ ).

First, theory predicts that public disclosure plays a more prominent coordination role for firms that compete in the same product market (e.g., Clinch and Verrecchia, 1997). 
Importantly, strategic alliances often consist of firms that directly compete in their respective product markets. This observation suggests that strategic alliances between direct competitors are more likely to involve the exchange of information that is beneficial for coordination (e.g., Teece, 1992). I measure the total number of direct competitors that firms form strategic alliances with (Competitor) as my first measure of PrivateInfo.

Second, while most strategic alliances involve only two firms, it is not uncommon to find alliances between three or more firms. When firms enter alliances with a greater number of participants, they are able to share more and a broader range of information. I measure the average number of participants involved in each of the firm's new alliances formed during the fiscal year (NParticipants) as my second measure of PrivateInfo.

Third, although strategic alliances take a variety of contractual forms in practice, one of the most common forms involve joint ventures, in which firms mutually commit resources and form a separate legal business entity that they each retain ownership and control rights over to pursue a project (Kogut, 1988). Several management studies argue that joint ventures represent a more hierarchical form of strategic alliance that more closely resembles a fully-integrated firm and leads to a greater degree of information sharing between partners (e.g., Balakrishnan and Koza, 1993; Anand and Khanna, 2000; Reuer and Koza, 2000; Anderson, Christ, Dekker, and Sedatole, 2014). I use an indicator for whether the firm forms at least one joint venture during the fiscal year (JointVenture) as my third measure of PrivateInfo.

Finally, Robinson and Stuart (2007), Dyer, Kale, and Singh (2001), and Anand and Khanna (2000) suggest that strategic alliances that involve R\&D or manufacturing activities create stronger information sharing networks among alliance partners than do 
many other types of alliances (e.g., supply or licensing agreements), since the complexity of $R \& D$ and manufacturing activities often require firms to learn more about their partners' operations. I use an indicator that equals one if the firm forms at least one alliance during the fiscal year that involves either R\&D or manufacturing activities (HighInfo) as my fourth measure of PrivateInfo.

\subsubsection{Results}

Table 5 presents results from estimating Eq. (2). For parsimony I do not report coefficients on control variables. In columns (1) through (4), for each of my four measures of PrivateInfo, I find that the coefficient on the interaction PrivateInfo $\times$ StrategicAlliance is negative and significantly related to firms' quantitative public voluntary disclosures (PrivateInfo $\times$ StrategicAlliance; coeffs $-0.281,-2.429,-1.526,-0.699 ;$-stats $-2.77,-$ $7.12,-5.68,-2.42)$. Moreover, columns (5) through (8) indicate that each of these results continues to hold when using my primary measure of qualitative topic of voluntary disclosure (ProductionDisclosure) as the dependent variable (PrivateInfo $\times$ StrategicAlliance; coeffs $-0.072,-0.430,-0.398,-0.485 ; t$-stats $-2.48,-3.20,-4.44,-$ 5.14). These results indicate that the relation between strategic alliances and voluntary disclosure is more pronounced for firms that enter into strategic alliances that involve private communication that involves more relevant information for coordination purposes, consistent with a greater reduction in the coordination benefits of disclosure for firms that enter into these types of strategic alliances. 


\section{Table 5. Cross Sectional Tests: The Degree of Private Communication in Strategic Alliances}

This table presents results from regressions of voluntary disclosure on strategic alliance activity conditional on the degree of private information exchange involved in firms' strategic alliances, for a sample of firms that form at least one new strategic alliance during the fiscal year. All variables are as defined in Appendix A. Columns (1) through (4) present results using my primary measure of voluntary disclosure (VolDisc). Columns (5) through (8) present results using firms' discussion of expected production and investment (ProductionDisc) to measure topic of public disclosure. Columns (1), (2), (3), and (4) present results using the count of the number of direct competitors that the firm formed strategic alliances with (Competitor), the average number of participants in each of the firms new strategic alliances (NParticipants), an indicator for whether the firm forms at least one equity-based joint venture during the year (JointVenture), and an indicator for whether the firm formed at least one R\&D or manufacturing alliance during the year (HighInfo) to measure PrivateInfo, respectively. For parsimony I do not tabulate coefficients on control variables. Each model includes untabulated Fama-French 12 industry fixed effects. $t$-statistics appear in parentheses and are clustered by firm. $* * *, * * *$ indicate statistical significance (two-sided) at the $0.1,0.05$, and 0.01 levels, respectively.

\section{Panel A. Quantitative Measure of Public Disclosure}

\begin{tabular}{lcccc}
\hline Dependent Variable: & \multicolumn{4}{c}{ VolDisc $_{t+1}$} \\
\cline { 2 - 5 } Measure of PrivateInfo: & Competitor & NParticipants & JointVenture & HighInfo \\
Variable & $(1)$ & $(2)$ & $(3)$ & $(4)$ \\
\hline \multirow{2}{*}{ PrivateInfo $\times$ StrategicAlliance } & $-0.281^{* * *}$ & $-2.429^{* * *}$ & $-1.526^{* * *}$ & $-0.699^{* *}$ \\
& $(-2.77)$ & $(-7.12)$ & $(-5.68)$ & $(-2.42)$ \\
PrivateInfo & $0.628^{* *}$ & $0.994^{* *}$ & 0.379 & -0.554 \\
& $(2.55)$ & $(2.19)$ & $(1.11)$ & $(-1.42)$ \\
StrategicAlliance & $-1.642^{* * *}$ & $3.366^{* * *}$ & $-1.031^{* * *}$ & $-1.473^{* * *}$ \\
& $(-8.34)$ & $(4.21)$ & $(-4.45)$ & $(-7.13)$ \\
\hline Controls & yes & yes & yes & yes \\
Fixed Effects & industry & industry & industry & industry \\
$\mathrm{F}$ & 52.38 & 55.47 & 53.73 & 56.23 \\
$\mathrm{~N}$ & 17,056 & 17,056 & 17,056 & 17,056 \\
\hline \hline
\end{tabular}

Panel B. Topic of Public Disclosure

\begin{tabular}{lcccc}
\hline \hline $\begin{array}{l}\text { Dependent Variable: } \\
\text { Measure of PrivateInfo: }\end{array}$ & \multicolumn{4}{c}{ ProductionDisc $t_{+1}$} \\
\cline { 2 - 5 } Variable & $\begin{array}{c}\text { Competitor } \\
(1)\end{array}$ & $\begin{array}{c}\text { NParticipants } \\
(2)\end{array}$ & $\begin{array}{c}\text { JointVenture } \\
(3)\end{array}$ & $\begin{array}{c}\text { HighInfo } \\
(4)\end{array}$ \\
\hline PrivateInfo $\times$ StrategicAlliance & $-0.072^{* *}$ & $-0.430^{* * *}$ & $-0.398^{* * *}$ & $-0.485^{* * *}$ \\
& $(-2.48)$ & $(-3.20)$ & $(-4.44)$ & $(-5.14)$ \\
PrivateInfo & $0.162^{* *}$ & 0.087 & 0.070 & $0.260^{* *}$ \\
& $(2.32)$ & $(0.52)$ & $(0.62)$ & $(2.27)$ \\
StrategicAlliance & $-0.155^{* * *}$ & $0.714^{* *}$ & 0.020 & 0.028 \\
& $(-2.73)$ & $(2.49)$ & $(0.32)$ & $(0.46)$ \\
\hline Controls & yes & yes & yes & yes \\
Fixed Effects & industry & industry & industry & industry \\
F & 23.57 & 27.23 & 30.44 & 28.68 \\
N & 17,056 & 17,056 & 17,056 & 17,056 \\
\hline \hline
\end{tabular}




\subsection{Limited private communication in strategic alliances}

\subsubsection{Research design}

While the preceding results focus on alliances that involve a greater degree of private communication among partners, certain types of alliances characteristics are less likely to facilitate extensive private communication between alliance partners, and I do not expect firms entering strategic alliances with these types of characteristics to reduce their public disclosure by as much. For this analysis, I re-estimate Eq. (2) after replacing PrivateInfo with two characteristics of firms' strategic alliances that involve limited private information exchange between strategic alliance partners (LimitedPrivateInfo).

First, prior management literature shows that licensing alliances involve the least amount of information spillovers between firms. For example, Anand and Khanna (2000) show that licensing alliances-i.e., alliances that involve firms cross-licensing their proprietary technology to each other-are the least likely types of alliances to facilitate information exchange due to the proprietary nature of the products, technology, or services being licensed. Therefore, I expect a weaker negative association between strategic alliances and voluntary disclosure for firms that enter licensing alliances. In this regard, my empirical tests associated with this prediction can be viewed as "falsification tests." I use an indicator that equals one if the firm forms at least one exclusive licensing alliance during the fiscal year, and zero otherwise (LowInfo) as my first measure of

\section{LimitedPrivateInfo.}

Second, I also expect firms that terminate their alliance relationships altogetherand therefore sever their private communication channels with their partners- to subsequently increase their voluntary disclosures. In this regard, my empirical tests 
associated with this prediction can be viewed as "treatment reversal tests." I use the total number of terminated alliances announced during the fiscal year (TerminatedAlliances) as my second measure of LimitedPrivateInfo.

\subsubsection{Results}

The results presented in Table 6 indicate that firms that enter low informationsharing alliances are not more likely to reduce their public disclosures (LowInfo $\times$ StrategicAlliance; coeffs $-0.096,0.065 ; t$-stats $-0.34,0.68$ in columns (1) and (3), respectively). Moreover, for each of my primary measures of quantitative and qualitative public disclosure, I find that firms that also announce strategic alliance terminations reduce their public disclosures by less (TerminatedAlliance $\times$ StrategicAlliance; coeffs 0.642 , 0.164 ; $t$-stats $2.67,1.63$ in columns (2) and (4), respectively). These results indicate that the observed relation between strategic alliances and public disclosure is less pronounced for firms that enter strategic alliances that involve limited private information exchange.

\section{Table 6. Falsification Test: Limited Private Communication in Strategic Alliances}

This table presents results from regressions of voluntary disclosure on strategic alliance activity conditional measures of limited information exchange between strategic alliance partners, for a sample of firms that form at least one new strategic alliance during the fiscal year. All variables are as defined in Appendix A. Columns (1) and (2) present results using my primary measure of voluntary disclosure (VolDisc). Columns (3) and (4) present results using firms' discussion of expected production and investment (ProductionDisc) to measure topic of public disclosure. Columns (1) and (2) present results using an indicator for whether the firm forms at least one exclusive licensing alliance during the year (LowInfo) and the count of the number of terminated alliances announced by the firm during the year (TerminatedAlliances) to measure LimitedPrivateInfo, respectively. For parsimony I do not tabulate coefficients on control variables. Each model includes untabulated Fama-French 12 industry fixed effects. $t$-statistics appear in parentheses and are clustered by firm. $* * *, * * *$ indicate statistical significance (two-sided) at the $0.1,0.05$, and 0.01 levels, respectively. 
Table 6. Falsification Test: Limited Private Communication in Strategic Alliances (cont'd)

\begin{tabular}{|c|c|c|c|c|}
\hline \multirow{2}{*}{$\begin{array}{l}\text { Dependent Variable: } \\
\text { Measure of } \\
\text { LimitedPrivateInfo: } \\
\text { Variable }\end{array}$} & \multicolumn{2}{|r|}{ VolDisc $_{t+1}$} & \multicolumn{2}{|c|}{ ProductionDisc $_{t+1}$} \\
\hline & $\begin{array}{l}\text { LowInfo } \\
(1)\end{array}$ & $\begin{array}{l}\text { TerminatedAlliances } \\
\text { (2) }\end{array}$ & $\begin{array}{c}\text { LowInfo } \\
(3)\end{array}$ & $\begin{array}{c}\text { TerminatedAlliances } \\
(4)\end{array}$ \\
\hline \multicolumn{5}{|l|}{ LimitedPrivateInfo $\times$} \\
\hline StrategicAlliance & $\begin{array}{l}-0.096 \\
(-0.34)\end{array}$ & $\begin{array}{l}0.642 * * * \\
(2.67)\end{array}$ & $\begin{array}{r}0.065 \\
(0.68)\end{array}$ & $\begin{array}{l}0.164 \\
(1.63)\end{array}$ \\
\hline LimitedPrivateInfo & $\begin{array}{c}-1.663 * * * \\
(-4.17)\end{array}$ & $\begin{array}{l}-1.987 * * * \\
(-3.71)\end{array}$ & $\begin{array}{l}-0.314 * * \\
(-2.44)\end{array}$ & $\begin{array}{l}-0.492 * * \\
(-2.36)\end{array}$ \\
\hline StrategicAlliance & $\begin{array}{l}-1.705 * * * \\
(-8.59) \\
\end{array}$ & $\begin{array}{l}-2.023^{* * *} \\
(-11.09) \\
\end{array}$ & $\begin{array}{l}-0.229 * * * \\
(-3.90)\end{array}$ & $\begin{array}{l}-0.247 * * * \\
(-4.50)\end{array}$ \\
\hline Controls & yes & yes & yes & yes \\
\hline Fixed Effects & industry & industry & industry & industry \\
\hline $\mathrm{F}$ & $55.69^{\circ}$ & 52.91 & $25.29^{\circ}$ & 24.36 \\
\hline $\mathrm{N}$ & 17,056 & 17,056 & 17,056 & 17,056 \\
\hline
\end{tabular}

4.4. Strategic alliances and industry characteristics: the degree of product market competition

\subsubsection{Research design}

An important prediction from Clinch and Verrecchia (1997) and Bertomeu and Liang (2015) is that the coordination benefits of disclosure are decreasing in the intensity of product market competition, as firms in more competitive industries benefit more from concealing information about expected demand from their competitors. For instance, in the context of Clinch and Verrecchia (1997), if a firm in a more competitive industry discloses information about stronger than expected demand, this is more likely to induce its competitors to cut their prices in the current period. Therefore, the coordination benefits of disclosure are lower in more competitive industries. To the extent that strategic alliances reduce the coordination benefits of disclosure, I expect a weaker association between strategic alliances and voluntary disclosure for firms in more competitive industries. I test 
for such a moderating effect of product market competition by interacting StrategicAlliance in Eq. (1) with measures of product market competition in the following specification:

$$
\begin{aligned}
\text { VolDisc }_{i, t+1}=\alpha & +\beta_{1} \text { Competition }_{i, t} \times \text { StrategicAlliance }_{i, t}+\beta_{2} \text { Competition }_{i, t} \\
& +\beta_{3} \text { StrategicAlliance }_{i, t}+\theta \text { Controls }+\varepsilon .
\end{aligned}
$$

I measure Competition using the following three measures: (i) $\mathrm{HHI}$ is the HerfindahlHirschman measure of industry concentration (as a percentage), (ii) Log(NumberFirms) is the natural logarithm of the total number of firms in the industry, and (iii) MktShareTop5 is the five-firm concentration ratio, measured as the market share of the five largest firms based on sales. I calculate all three competition measures annually based on Fama-French12 industry groups. ${ }^{15}$ To facilitate comparison across the measures, I use the negative value of HHI and MarketShare so that all three measures of Competition are increasing in the degree of product market competition. If firms in more competitive industries are less likely to use public disclosure to coordinate prior to strategic alliance formation, I expect to find $\beta_{1}>0 .{ }^{16}$

\subsubsection{Results}

Table 7 presents results from estimating Eq. (3). For each measure of Competition, I find that the coefficient on the interaction term Competition $\times$ StrategicAlliance is positively associated with voluntary disclosure (coeffs $0.249,0.287,4.103,0.096,0.182$,

\footnotetext{
${ }^{15}$ All of my results are qualitatively similar -i.e., of the same sign and level of statistical significance - when using finer definitions of industry membership (e.g., two-digit SIC codes) to measure Competition when estimating Eq. (3).

${ }^{16}$ In supplementary analyses, I also explore cross-sectional settings where managers likely have more discretion in using public disclosure as a coordination mechanism-when their firms' ex ante information environment is already sufficiently rich. Results presented in Table IA2 suggest that my findings are concentrated among firms with higher quality external information, consistent with these firms having a lower cost of removing public disclosure.
} 
$1.779 ; t$-stats $6.24,2.77,5.64,4.55,4.21,4.97$, respectively), indicating that the reduction in firms' voluntary disclosure for firms that enter strategic alliances is muted in more competitive industries. Collectively, these results are consistent with theories suggesting that the coordination benefit of public information exchange is decreasing in the degree of product market competition.

\section{Table 7. Cross Sectional Tests: Industry Characteristics}

This table presents results from regressions of voluntary disclosure on strategic alliance activity conditional on product market competition. All variables are as defined in Appendix A. Columns (1) through (3) present results using my primary measure of voluntary disclosure (VolDisc). Columns (4) through (6) present results using firms' discussion of expected production and investment (ProductionDisc) to measure topic of public disclosure. Columns (1), (2), and (3) present results using Herfindahl-Hirschman industry concentration multiplied by $(-1)(H H I)$, the natural log of the number of firms in the industry $(\log ($ NumFirms $))$, and the five-firm concentration ratio multiplied by $(-1)$ (MktShareTop5) to measure Competition, respectively. Panel B presents results for information quality. Columns (1) and (2) present results using my primary measure of voluntary disclosure (VolDisc). For parsimony I do not tabulate coefficients on control variables. Each model includes untabulated Fama-French 12 industry fixed effects. $t$-statistics appear in parentheses and are clustered by firm. $* * *, * * *$ indicate statistical significance (two-sided) at the $0.1,0.05$, and 0.01 levels, respectively.

\section{Panel A. Quantitative Measure of Public Disclosure}

\begin{tabular}{lccc}
\hline \hline \multirow{2}{*}{$\begin{array}{l}\text { Dependent Variable: } \\
\text { Measure of Competition: }\end{array}$ Variable } & HHI & Log(NumFirms) & MktShareTop5 \\
\cline { 2 - 4 } & $(1)$ & $(2)$ & $(3)$ \\
\hline \multirow{2}{*}{ Competition $\times$ StrategicAlliance } & $0.249^{* * *}$ & $0.287^{* * *}$ & $4.103^{* * *}$ \\
& $(6.24)$ & $(2.77)$ & $(5.64)$ \\
Competition & -0.071 & $-10.427^{* * *}$ & $-6.520^{* * *}$ \\
& $(-0.92)$ & $(-44.77)$ & $(-5.97)$ \\
StrategicAlliance & $-0.398^{* * *}$ & $-2.502^{* * *}$ & 0.055 \\
& $(-2.61)$ & $(-3.60)$ & $(0.24)$ \\
\hline Controls & yes & yes & yes \\
Fixed Effects & industry & industry & industry \\
F & 179.1 & 238.0 & 179.1 \\
$\mathrm{~N}$ & 115,912 & 115,912 & 115,912 \\
\hline \hline
\end{tabular}




\section{Table 7. Cross Sectional Tests: Industry Characteristics (cont'd)}

\section{Panel B. Topic of Public Disclosure}

\begin{tabular}{|c|c|c|c|}
\hline \multirow{2}{*}{$\begin{array}{l}\text { Dependent Variable: } \\
\text { Measure of Competition: } \\
\text { Variable }\end{array}$} & \multicolumn{3}{|c|}{ ProductionDisc $_{t+1}$} \\
\hline & $\begin{array}{l}H H I \\
(4)\end{array}$ & $\begin{array}{c}\log (\text { NumFirms }) \\
(5)\end{array}$ & $\begin{array}{c}\text { MktShareTop5 } \\
\text { (6) }\end{array}$ \\
\hline Competition $\times$ StrategicAlliance & $\begin{array}{l}0.096^{* * * *} \\
(4.55)\end{array}$ & $\begin{array}{l}0.182 * * * \\
(4.21)\end{array}$ & $\begin{array}{l}1.779^{* * *} \\
(4.97)\end{array}$ \\
\hline Competition & $\begin{array}{l}-0.127 * * * \\
(-6.00)\end{array}$ & $\begin{array}{l}-2.293^{* * *} \\
(-45.44)\end{array}$ & $\begin{array}{l}-4.073^{* * *} \\
(-12.92)\end{array}$ \\
\hline StrategicAlliance & $\begin{array}{c}0.109^{*} \\
(1.80) \\
\end{array}$ & $\begin{array}{l}-1.254^{* * *} \\
(-4.27)\end{array}$ & $\begin{array}{l}0.341^{* * *} \\
(3.44)\end{array}$ \\
\hline Controls & yes & yes & yes \\
\hline Fixed Effects & industry & industry & industry \\
\hline $\mathrm{F}$ & $143.1^{\circ}$ & 338.4 & 151.8 \\
\hline $\mathrm{N}$ & 115,912 & 115,912 & 115,912 \\
\hline
\end{tabular}

\subsection{Quasi-natural experiment: staggered adoption of combined reporting regimes}

\subsubsection{Research design}

In my final set of tests, I use the staggered adoption of combined reporting tax rules in various states as an arguably exogenous shock that increased firms' incentives to form strategic alliances. My prior tests take firms' strategic alliance activity as exogenous from the perspective of my research question, and assume that the coordination benefits of private communication are an incidental by-product of strategic alliances that affects firms' public disclosures. These tests allow me to assess whether my results continue to hold in a setting that involves arguably exogenous variation in firms' strategic alliance activity (e.g., Bodnaruk, Massa, and Simonov, 2013; Li, Qiu, and Wang, 2018).

During my sample period, many states adopted combined reporting rules for corporate state tax purposes that reduced the opportunity cost of forming strategic alliances. Under separate reporting rules, firms with operations in multiple states are able to shift income of their most profitable operations to states with lower corporate tax rates (e.g., 
Dyreng, Lindsey, and Thornock, 2013; Armstrong, Glaeser, and Kepler, 2018). However, combined reporting rules require the firm to report its total domestic income and pay state income taxes based on the proportion of its activity in that state. Thus, combined reporting rules limit multi-state firms' ability to shift income to subsidiaries located in states with lower corporate tax rates, which reduces firms' incentives to rely on internal capital markets to be able to transfer assets across subsidiaries to minimize their state taxes (Mazerov, 2002, 2009). ${ }^{17}$ Firms that allocate capital to strategic alliances are unable to engage in such asset transfers in the first place, which represent a major "opportunity cost" of engaging in strategic alliances (Bodnaruk, Massa, and Simonov, 2013; Li, Qiu, and Wang, 2018). Thus, by impeding firms' ability to transfer assets across state lines to reduce their tax burdens, combined reporting rules reduce the cost of forming strategic alliances and increase firms' incentives to form strategic alliances. Figure 2 reports the states that adopted combined reporting rules during my sample period.

\footnotetext{
${ }^{17}$ In particular, Mazerov (2009) notes that "[b]y requiring corporate parents and subsidiaries to add their profits together, combined reporting states are able to nullify a variety of tax-avoidance strategies large multistate corporations have devised to artificially move profits out of the states in which they are earned and into states in which they will be taxed at lower rates."
} 


\section{Figure 2. Combined Reporting Regime Staggered Adoption}

This figure presents the geographic distribution of states requiring combined reporting of corporate income (Mazerov, 2009; Dyreng, Lindsey, and Thornock, 2013). Sixteen U.S. states (grey) adopted combined reporting prior to the start of my sample period in 1994 and nine states plus the District of Columbia (striped) adopted combined reporting during my sample period between 1994 and 2012.
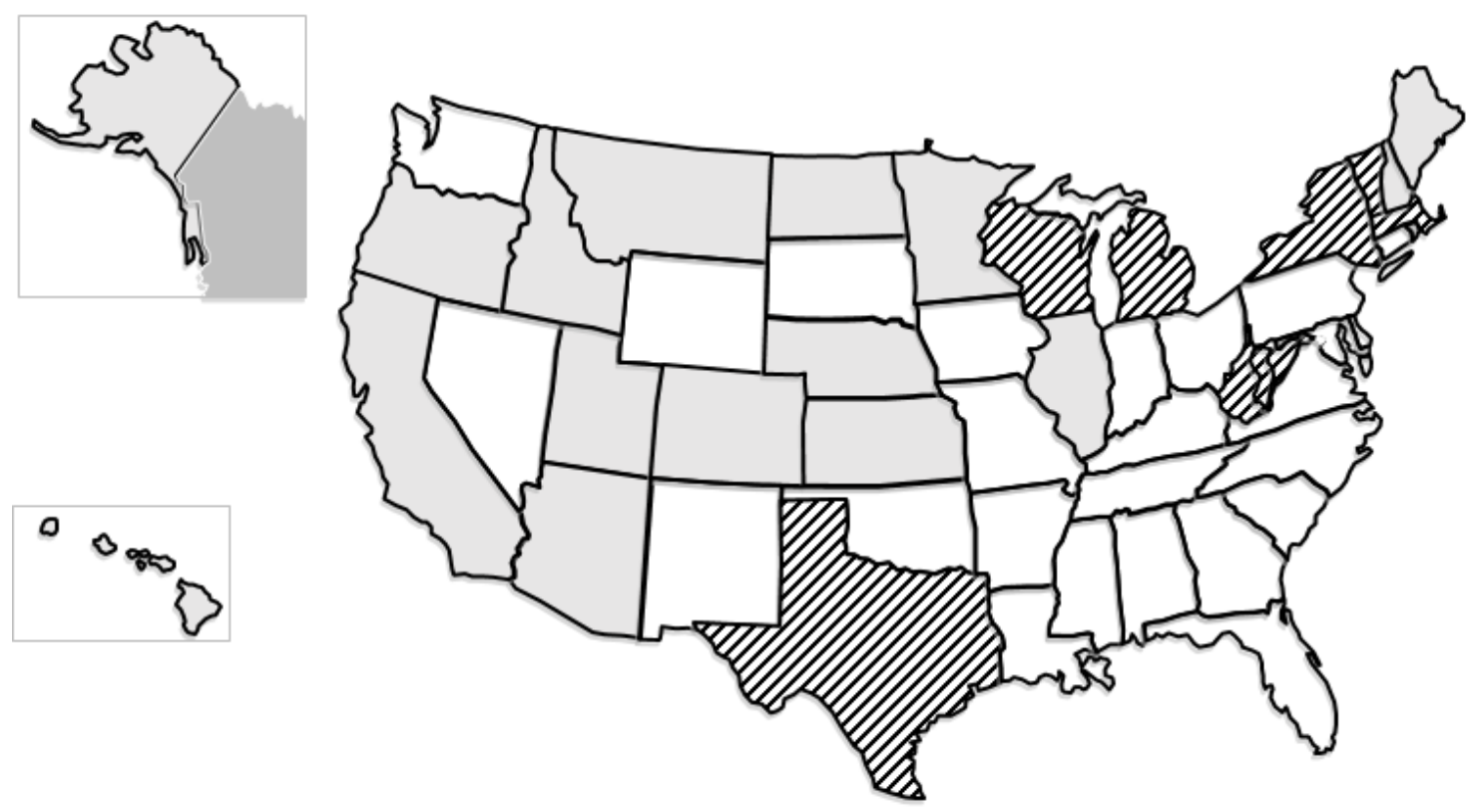

Combined Combined

Reporting

State Adoption Year

Reporting

Alaska

$<1994$

State Adoption Year

Arizona

$<1994$

Minnesota

$<1994$

California

$<1994$

Montana

$<1994$

Colorado

$<1994$

Nebraska

$<1994$

District of Columbia

2011

New Hampshire

$<1994$

Georgia

2010

New York

2007

Hawaii

$<1994$

Idaho

$<1994$

North Carolina

2012

Illinois

$<1994$

North Dakota

$<1994$

Kansas

$<1994$

Oregon

$<1994$

Maine

$<1994$

Massachusetts

2008

Utah

2008

Michigan

2008

Vermont

$<1994$

2006

West Virginia 2009

Wisconsin

2009 
In order to implement these tests, I estimate the following generalized differencein-differences specification:

$$
\text { VolDisc } i, t=\alpha+\beta_{1} \text { CombinedReportingRegime }_{i, t}+\theta \text { Controls }+\delta_{i}+\gamma_{t}+\varepsilon .
$$

I use both quantitative and qualitative measures of disclosure (i.e., VolDisc and ProductionDisc, respectively) when estimating Eq. (4). CombinedReportingRegime is an indicator equal to one if the firm's headquarters for a given firm-year is located in a state that has adopted combined reporting rules, and zero otherwise. I obtain information on firms' state of headquarters from the authors of Jennings, Lee, and Matsumoto (2017), who "scrape" firm's annual 10-K filings to identify each firm's current headquarter state each year. ${ }^{18}$ When estimating Eq. (4) I include firm fixed effects $\left(\delta_{i}\right)$ to control for time-invariant firm characteristics (e.g., since certain types of firms are inherently more likely to form alliances), and I include year fixed effects $\left(\gamma_{t}\right)$ to control for macroeconomic shocks and time trends (e.g., the increasing trend over my sample period for states to adopt combined reporting rules). I also re-estimate Eq. (4) after augmenting each model with state headquarter fixed effects to control for systematic differences across firms headquartered in different states (e.g., differences in local industry clustering across states; Armstrong, Glaeser, Huang, and Taylor, 2018). All other variables are as previously defined.

\subsubsection{Results}

\footnotetext{
${ }^{18}$ All of my results from estimating Eq. (4) are qualitatively similar-i.e., of the same sign and level of statistical significance - if I use a subsidiary-weighted average measure of firms' exposure to states that adopt combined reporting rules in lieu of CombinedReportingRegime. I obtain information on firms' subsidiary locations from the authors of Dyreng, Lindsey, and Thornock (2013), who scrape firms' Exhibit 21 filings with the SEC for the states of firms' material subsidiaries.
} 
Table 8 presents results from implementing my quasi-natural experiment. Panel A presents descriptive statistics for the treatment variable, CombinedReportingRegime. Across my entire sample, $38 \%$ of firm-years are headquartered in states that have adopted combined reporting rules. Panel B presents univariate differences for firms' strategic alliance activity and voluntary disclosure conditional on CombinedReportingRegime. Panel B1 presents the average likelihood that the firm forms at least one new strategic alliance conditional on whether it is headquartered in a combined reporting regime state. Results indicate that firms are 2 percentage points $(=0.15-0.13)$ more likely to form strategic alliances when headquartered in states that have adopted combined reporting regimes. Panel B2 presents univariate differences in my primary and alternate measures of firms' voluntary disclosure (VolDisc and ProductionDisc) conditional on whether it (i) forms new strategic alliances during the fiscal year (StrategicAllianceInd) and (ii) is headquartered in a combined reporting state. Results indicate that firms that are headquartered in states that have adopted combined reporting and form new strategic alliance, on average, provide less voluntary disclosure than their counterparts that are headquartered in states that do not have combined reporting rules (i.e., a difference-indifferences of $-0.31(-0.21)$ when using VolDic (ProductionDisc) as a measure of voluntary disclosure). 


\section{Table 8. Quasi-Natural Experiment: Combined Reporting Rules}

This table presents results from a generalized difference-in-differences estimation using state adoption of combined reporting rules, following Bodnaruk, Massa, and Simonov (2013) and Li, Qiu, and Wang (2018), as a shock to the benefits of forming strategic alliances. CombinedReportingRegime is an indicator equal to one if the firm is headquartered in a state that has adopted combined reporting rules, and zero otherwise, using firms' state of headquarter data from Jennings, Lee, and Matsumoto (2017). All other variables are as defined in Appendix A. Panel A presents descriptive statistics for the treatment variable, CombinedReportingRegime. Panel B presents univariate differences for firms' strategic alliance activity and voluntary disclosure conditional on CombinedReportingRegime. Panel B1 presents the average likelihood that the firm forms at least one new strategic alliance conditional on whether it is headquartered in a combined reporting regime state or not. Panel B2 presents univariate differences in my primary and alternate measures firms' voluntary disclosure (VolDisc and ProductionDisc) conditional on (i) whether it forms new strategic alliances during the fiscal year (NewStrategicAlliance) as well as (ii) whether it is headquartered in a combined reporting state or not. Panel $\mathrm{C}$ presents results from a generalized difference-in-differences estimate with untabulated firm and year fixed effects in columns (1) and (3) and untabulated firm, year, and state headquarter fixed effects in columns (2) and (4). Columns (1) and (2) of Panel C presents results using my primary measure of voluntary disclosure (VolDisc). Columns (3) and (4) of Panel C presents results using firms' discussion of expected production and investment (ProductionDisc) to measure topic of public disclosure. $t$-statistics appear in parentheses and are clustered by firm. $*, * *, * * *$ indicate statistical significance (two-sided) at the 0.1, 0.05, and 0.01 levels, respectively. Sample period is 1994 through 2012.

Panel A. Descriptive Statistics

\begin{tabular}{lcccccc}
\hline \hline Variable & $\mathrm{N}$ & Mean & Std & 25 th & Median & 75th \\
\hline CombinedReportingRegime & 94,477 & 0.38 & 0.48 & 0.00 & 0.00 & 1.00 \\
\hline \hline
\end{tabular}

\section{Panel B1. Combined Reporting Rules and Differences in Strategic Alliance Activity}

Mean StrategicAllianceInd

\begin{tabular}{cccc}
\hline $\begin{array}{c}\text { Non-Combined } \\
\text { Reporting Regime }\end{array}$ & $\begin{array}{c}\text { Combined } \\
\text { Reporting Regime }\end{array}$ & Diff. & {$[p$-value $]$} \\
\hline 0.13 & 0.15 & $0.02^{* * *}$ & {$[<0.001]$} \\
\hline \hline
\end{tabular}

Panel B2. Univariate Difference-in-Differences of Public Disclosure

\begin{tabular}{|c|c|c|c|c|}
\hline & $\begin{array}{l}\text { Non-Combined } \\
\text { Reporting } \\
\text { Regime }\end{array}$ & $\begin{array}{c}\text { Combined } \\
\text { Reporting } \\
\text { Regime }\end{array}$ & & \\
\hline & \multicolumn{2}{|c|}{ Mean VolDisc } & Diff. & [p-value $]$ \\
\hline StrategicAllianceInd $=0$ & 2.11 & 3.39 & $1.28^{* * *}$ & {$[<0.001]$} \\
\hline StrategicAllianceInd $=1$ & 3.40 & 4.37 & $0.97 * * *$ & {$[<0.001]$} \\
\hline $\begin{array}{c}\text { Diff. } \\
{[p \text {-value }]}\end{array}$ & $\begin{array}{c}1.29 * * * \\
{[<0.001]}\end{array}$ & $\begin{array}{r}0.98 * * * \\
{[<0.001]}\end{array}$ & $\begin{array}{l}-0.31 * * * \\
{[<0.001]}\end{array}$ & $\begin{array}{c}\text { Diff.-in-Diff. } \\
\text { [p-value }]\end{array}$ \\
\hline \multicolumn{5}{|c|}{ Mean ProductionDisc } \\
\hline StrategicAllianceInd $=0$ & 2.24 & 2.57 & $0.33^{* * *}$ & {$[<0.001]$} \\
\hline StrategicAllianceInd $=1$ & 2.73 & 2.85 & $0.12 * * *$ & {$[<0.001]$} \\
\hline $\begin{array}{c}\text { Diff. } \\
{[p \text {-value }]}\end{array}$ & $\begin{array}{c}0.49 * * * \\
{[<0.001]}\end{array}$ & $\begin{array}{r}0.28 * * * \\
{[<0.001]}\end{array}$ & $\begin{array}{l}-0.21 * * * \\
{[<0.001]}\end{array}$ & $\begin{array}{l}\text { Diff.-in-Diff. } \\
\text { [p-value }]\end{array}$ \\
\hline
\end{tabular}


Panel C presents results from estimating Eq. (4). Columns (1) and (2) of Panel C present results using my primary measure of voluntary disclosure (VolDisc). Column (3) and (4) of Panel C presents results using firms' discussion of expected production and investment (ProductionDisc) to measure the topic of public disclosure. Columns (1) and (3) present results with firm and year fixed effects, and Columns (2) and (4) present results with firm, year, and state fixed effects. Across each specification, I find that firms subject to combined reporting rules subsequently reduce their quantitative and qualitative public disclosures (CombinedReportingRegime; coeffs $-0.317 ;-0.351 ;-0.107 ;-0.110 ; t$-stats $2.01 ;-1.89 ;-3.46 ;-3.34) .{ }^{19,20}$

\footnotetext{
${ }^{19}$ The coefficient on CombinedReportingRegime in column (1) of Panel C of -0.317 represents approximately $5 \%$ of my sample standard deviation of management forecast frequency.

${ }^{20}$ I also re-estimate Eq. (4) using a two-stage least squares procedure using CombinedReportingRegime as an instrument for StrategicAlliance. In untabulated analyses, I find that CombinedReportingRegime has a significant positive relation with StrategicAlliance in the first-stage, and the instrumented StrategicAlliance in the second-stage has a significant negative relation with my primary measures of public disclosure (i.e., VolDisc and ProductionDisc).
} 
Table 8. Quasi-Natural Experiment: Combined Reporting Rules (cont'd)

Panel C. Generalized Difference-in-Differences

\begin{tabular}{|c|c|c|c|c|}
\hline \multirow{2}{*}{$\begin{array}{l}\text { Dependent Variable: } \\
\text { Variable }\end{array}$} & \multicolumn{2}{|c|}{ VolDisc $_{t}$} & \multicolumn{2}{|c|}{ ProductionDisc $_{t}$} \\
\hline & (1) & (2) & (3) & (4) \\
\hline $\begin{array}{l}\text { CombinedReportingRegi } \\
\text { me }\end{array}$ & $\begin{array}{l}-0.317^{* *} \\
(-2.01)\end{array}$ & $\begin{array}{l}-0.351^{*} \\
(-1.89)\end{array}$ & $\begin{array}{l}-0.107^{* * * *} \\
(-3.46)\end{array}$ & $\begin{array}{l}-0.110^{* * *} \\
(-3.34)\end{array}$ \\
\hline Controls & & & & \\
\hline Size & $\begin{array}{l}0.794 * * * \\
(15.00)\end{array}$ & $\begin{array}{l}0.798^{* * *} \\
(15.07)\end{array}$ & $\begin{array}{l}0.265^{* * *} \\
(23.12)\end{array}$ & $\begin{array}{l}0.262^{* * *} \\
(22.90)\end{array}$ \\
\hline SalesVol & $\begin{array}{l}-1.056^{* * * *} \\
(-4.03)\end{array}$ & $\begin{array}{l}-1.059 * * * \\
(-4.04)\end{array}$ & $\begin{array}{l}0.343 * * * \\
(5.93)\end{array}$ & $\begin{array}{l}0.342 * * * \\
(5.91)\end{array}$ \\
\hline BTM & $\begin{array}{l}0.457^{* * *} \\
(9.10)\end{array}$ & $\begin{array}{l}0.457^{* * *} \\
(9.10)\end{array}$ & $\begin{array}{l}0.120^{* * *} \\
(8.15)\end{array}$ & $\begin{array}{l}0.119^{* * *} \\
(8.12)\end{array}$ \\
\hline Leverage & $\begin{array}{l}1.435 * * * \\
(6.54)\end{array}$ & $\begin{array}{l}1.483^{* * *} \\
(6.79)\end{array}$ & $\begin{array}{l}0.669 * * * \\
(12.77)\end{array}$ & $\begin{array}{l}0.670^{* * *} \\
(12.84)\end{array}$ \\
\hline$R O A$ & $\begin{array}{l}0.514 * * * \\
(3.36)\end{array}$ & $\begin{array}{l}0.530^{* * * *} \\
(3.47)\end{array}$ & $\begin{array}{l}-0.181 * * * \\
(-3.56)\end{array}$ & $\begin{array}{l}-0.176^{* * *} \\
(-3.47)\end{array}$ \\
\hline SpecItems & $\begin{array}{l}-1.381 * * * \\
(-4.57)\end{array}$ & $\begin{array}{l}-1.410^{* * *} \\
(-4.67)\end{array}$ & $\begin{array}{l}-0.299 * * * \\
(-2.74)\end{array}$ & $\begin{array}{l}-0.301 * * * \\
(-2.77)\end{array}$ \\
\hline Loss & $\begin{array}{l}-0.519 * * * \\
(-9.36)\end{array}$ & $\begin{array}{l}-0.517 * * * \\
(-9.37)\end{array}$ & $\begin{array}{l}0.125^{* * *} \\
(7.83)\end{array}$ & $\begin{array}{l}0.125^{* * *} \\
(7.81)\end{array}$ \\
\hline Returns & $\begin{array}{l}-0.467 * * * \\
(-17.76)\end{array}$ & $\begin{array}{l}-0.467^{* * * *} \\
(-17.77)\end{array}$ & $\begin{array}{l}-0.063 * * * \\
(-7.02)\end{array}$ & $\begin{array}{l}-0.062^{* * *} \\
(-6.91)\end{array}$ \\
\hline IdioVol & $\begin{array}{l}-2.106^{* * *} \\
(-8.08)\end{array}$ & $\begin{array}{l}-2.106^{* * *} \\
(-8.09)\end{array}$ & $\begin{array}{l}1.156^{* * *} \\
(13.23)\end{array}$ & $\begin{array}{l}1.150^{* * *} \\
(13.15)\end{array}$ \\
\hline NumSegments & $\begin{array}{l}0.311 * * * \\
(8.29)\end{array}$ & $\begin{array}{l}0.313 * * * \\
(8.36)\end{array}$ & $\begin{array}{l}0.018^{* *} \\
(2.38)\end{array}$ & $\begin{array}{l}0.018 * * \\
(2.42)\end{array}$ \\
\hline R\&D-to-Sales & $\begin{array}{l}-0.054 \\
(-1.39)\end{array}$ & $\begin{array}{l}-0.050 \\
(-1.29)\end{array}$ & $\begin{array}{r}0.011 \\
(0.82) \\
\end{array}$ & $\begin{array}{r}0.011 \\
(0.77) \\
\end{array}$ \\
\hline Fixed Effects & firm, year & firm, year, state & firm, year & firm, year, state \\
\hline $\mathrm{F}$ & 58.27 & 58.54 & 77.40 & 76.19 \\
\hline $\mathrm{N}$ & 94,477 & 94,477 & 94,477 & 94,477 \\
\hline
\end{tabular}

\subsection{Additional analyses}

Standard models of voluntary disclosure (e.g., Dye, 1985; Jung and Kwon, 1986; Verrecchia, 1990) suggest four general economic forces that lead to a reduction in voluntary disclosure: (i) an increase in bad news, (ii) an increase in proprietary costs, (iii) a decrease in managers' private information, and (iv) a decrease in investors' uncertainty. To explain my collective results, these forces would need to systematically vary with firms' 
strategic alliance activity, with the attributes of strategic alliances, with product market competition, and with the staggered adoption of combined reporting rules. While I view this as unlikely, nevertheless, I conduct a number of additional analyses designed to mitigate concerns about these forces in my setting.

First, with regard to an increase in bad news, I examine capital market reactions to strategic alliance announcements. I find that strategic alliance announcements are, on average, significant good news events (mean announcement date abnormal return of $0.43 \%$ ), see Figure 3 . This finding suggests the decline in disclosure is not attributable to an increase in bad news. Second, with regard to an increase in proprietary costs, each of my tables report similar results for disclosures likely to be proprietary in nature (e.g., demand and production information) and disclosures likely to be non-proprietary in nature (e.g., management earnings forecasts; e.g., Lang and Sul, 2014; Glaeser, 2018). In addition, Table 7 shows that my results are concentrated in less competitive industries-i.e., industries commonly thought to have low proprietary costs. These findings suggest the decline in disclosure is not attributable to an increase in proprietary costs. Third, with regard to a decrease in managers' private information, in Tables IA3 and IA4, I examine (i) the relation between strategic alliances and the accuracy of management forecasts and (ii) the relation between strategic alliances and insider trading, respectively. I do not find any evidence of a relation between alliance activity and management forecast accuracy, but I do find a strong positive relation between alliance activity and insider trading. These findings are inconsistent with strategic alliances reducing managers' private information. Finally, with regard to a decrease in investors' uncertainty, in Table IA5, I examine the relation between strategic alliances and the bid/ask spread. I find a strong positive relation 
between alliance activity and the bid/ask spread. These findings are inconsistent with strategic alliances reducing investors' uncertainty.

\section{Figure 3. Strategic Alliances, Trading Volume, and Abnormal Returns}

This figure plots normalized total trading volume (PublicVolume) and abnormal daily stock returns (AllianceAnnouncementReturn) in the $[-20,+20]$ window around the public disclosure of the strategic alliances included in my sample. Day 0 is the date of the public disclosure of the strategic alliance announcement. Panel A presents average daily normalized total trading volume (PublicVolume) around the public disclosure of the strategic alliance, where PublicVolume is total trading volume minus average daily trading volume over my entire sample, scaled by the standard deviation of daily volume over my entire sample. Panel B presents average abnormal daily stock return (AllianceAnnouncementReturn) around the public disclosure of the strategic alliance. Sample consists of 40,282 strategic alliance announcements for firms appearing on Compustat, CRSP, and SDC Platinum's Alliances and Joint Ventures database from 1994 to 2014 .

Panel A. Strategic Alliance Announcement Normalized Trading Volume

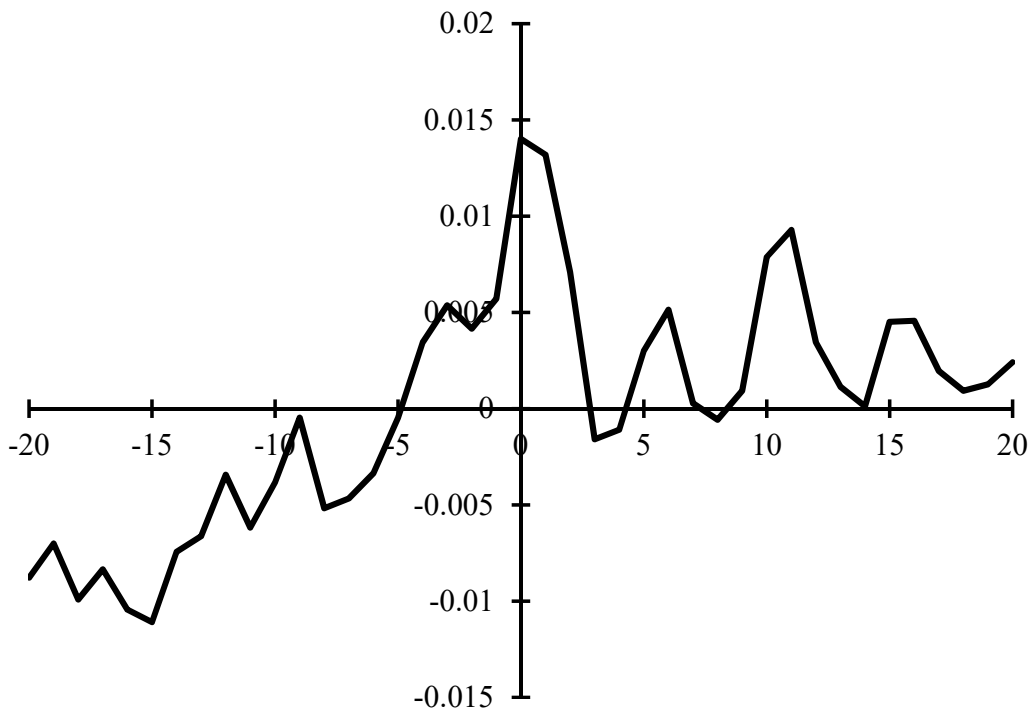


Figure 3. Strategic Alliances, Trading Volume, and Abnormal Returns (cont'd) Panel B. Strategic Alliance Announcement Abnormal Returns (\%)

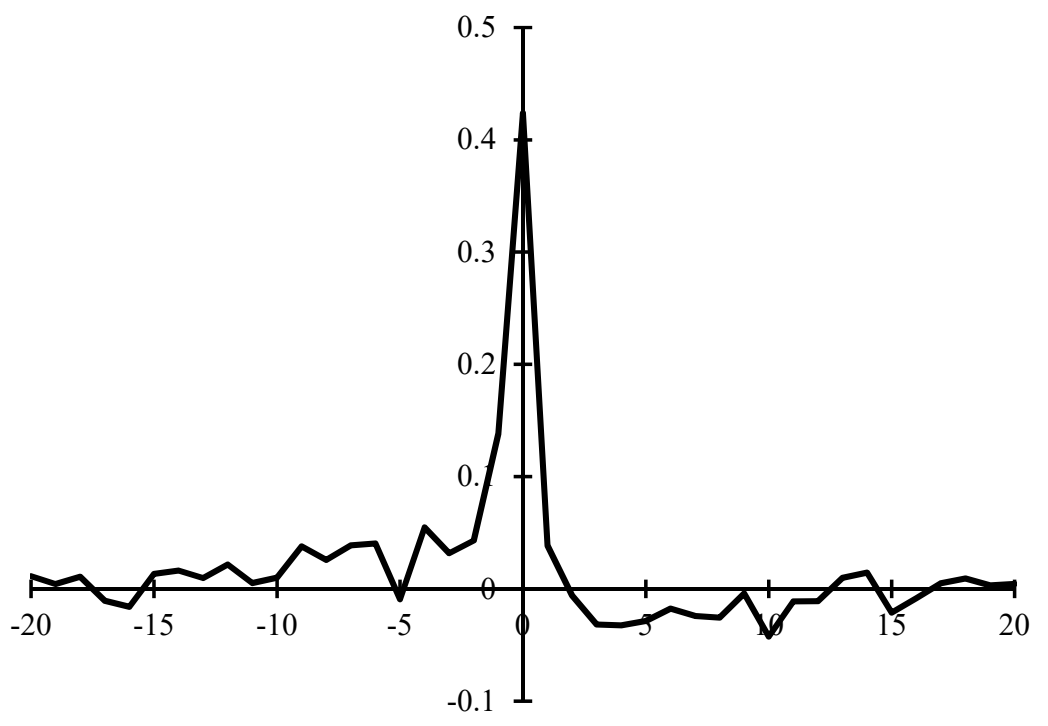

\section{Conclusion}

Theories at the intersection of accounting and industrial organization suggest that public disclosure can facilitate coordination among competitors. Much of this literature implicitly assumes that competitors cannot privately communicate production and pricing decisions and must rely on public disclosures to do so. Building on these theories, I exploit data on the extent of private communication between firms within strategic alliances, and examine how private communication among competitors manifests in public disclosure decisions. Strategic alliances provide a direct channel for private communication between firms that arguably reduces any coordination benefits of public disclosure.

Consistent with my predictions, I find that firms that enter into strategic alliances with competitors reduce their public disclosure about expected future business conditions — and specifically about forecasted demand and production levels — and that the 
reduction is most (least) pronounced for firms in alliances that entail more (less) extensive private communication and less pronounced among firms in competitive industries. Finally, I use the staggered adoption of state tax rules that increased the benefits of forming strategic alliances as an exogenous shock to strategic alliance activity, and find greater reductions in public disclosures among affected firms.

Thus, while much of the prior disclosure literature focuses on the monitoring and valuation roles of public disclosure, my collective results provide evidence of an important additional role of public disclosure: facilitating coordination among competitors. In this regard, my study represents a first step in moving beyond the standard valuation and monitoring paradigms that dominate much of the disclosure literature. 


\section{APPENDIX}

\section{Appendix A. Variable Definitions}

This appendix provides definitions for the key variables used in my tests.

\begin{tabular}{|c|c|}
\hline \multicolumn{2}{|c|}{ trategic alliance characteristics } \\
\hline StrategicAlliance & $\begin{array}{l}\text { Natural } \log \text { of } 1 \text { plus the total number of new strategic alliance } \\
\text { agreements entered into by the firm during the fiscal year. }\end{array}$ \\
\hline StrategicAllianceInd & $\begin{array}{l}\text { Indicator that equals one if the firm entered into one or more strategic } \\
\text { alliances during the fiscal year, and zero otherwise. }\end{array}$ \\
\hline Competitor & $\begin{array}{l}\text { Count of the number of strategic alliances entered into during the } \\
\text { fiscal year with other firms that operate in the same Fama-French } 12 \\
\text { industry as the firm. }\end{array}$ \\
\hline JointVenture & $\begin{array}{l}\text { Indicator for whether the firm formed at least one equity-based joint } \\
\text { venture during the fiscal year, and zero otherwise. }\end{array}$ \\
\hline NParticipants & $\begin{array}{l}\text { Average number of participants involved in all of the new alliances } \\
\text { that the firm enters into during the year. }\end{array}$ \\
\hline HighInfo & $\begin{array}{l}\text { Indicator that equals one if the firm entered into at least one } \\
\text { manufacturing or } R \& D \text { alliance during the year, and zero otherwise. }\end{array}$ \\
\hline LowInfo & $\begin{array}{l}\text { Indicator that equals one if the firm entered into at least one exclusive } \\
\text { licensing alliance during the year, and zero otherwise. }\end{array}$ \\
\hline TerminatedAlliances & $\begin{array}{l}\text { Count of the number of strategic alliance terminations announced by } \\
\text { the firm during the fiscal year. }\end{array}$ \\
\hline AllianceAnnouncementReturn & $\begin{array}{l}\text { Abnormal stock return on the strategic alliance announcement date, } \\
\text { in percent. }\end{array}$ \\
\hline PublicVolume & $\begin{array}{l}\text { Total CRSP trading volume on the strategic alliance announcement } \\
\text { date minus average daily total CRSP trading volume over my entire } \\
\text { sample, scaled by the standard deviation of total CRSP insider } \\
\text { volume over my entire sample. }\end{array}$ \\
\hline \multicolumn{2}{|l|}{ Public disclosure measures } \\
\hline VolDisc & $\begin{array}{l}\text { Number of management forecasts issued over the } 12 \text { months } \\
\text { following the fiscal year-end. }\end{array}$ \\
\hline CapExDisc & $\begin{array}{l}\text { Number of management capital expenditure forecasts issued over the } \\
12 \text { months following the fiscal year-end. }\end{array}$ \\
\hline SalesDisc & $\begin{array}{l}\text { Number of management sales forecasts issued over the } 12 \text { months } \\
\text { following the fiscal year-end. }\end{array}$ \\
\hline ProductionDisc & $\begin{array}{l}\text { Natural log of the total number of times the firm mentions } \\
\text { "quantity", "product", "invest", "capital expenditure", "pricing", } \\
\text { including wildcard operators (e.g., "investment", "production", } \\
\text { "product quantities", etc.) in an 8-K issued over the } 12 \text { months } \\
\text { following the fiscal year-end. }\end{array}$ \\
\hline MarketDemandDisc & $\begin{array}{l}\text { Natural } \log \text { of the total number of times the firm mentions "demand", } \\
\text { "business condition", or "market condition", including wildcard } \\
\text { operators (e.g., "market conditions", "business demands", etc.) in an } \\
\text { 8-K issued over the } 12 \text { months following the fiscal year-end. }\end{array}$ \\
\hline
\end{tabular}

Controls

Size Natural log of the book value of equity as of the end of the fiscal
year.

SalesVol Standard deviation of annual sales over the most recent ten fiscal years. 
$B T M$

Leverage

$R O A$

SpecItems

Loss

Returns

IdioVol

NumSegments

$R \& D$-to-Sales

Competition measures

$H H I$

Log(NumFirms)

MktShareTop5
Book value of equity scaled by the market value of equity as of the end of the fiscal year.

Total liabilities scaled by total assets as of the end of the fiscal year.

Income before extraordinary items scaled by total assets as of the end of the fiscal year.

Special items for the current fiscal year scaled by total assets as of the end of the fiscal year.

Indicator that equals one if income before extraordinary items is negative, and zero otherwise.

The firm's buy and hold stock return over the 12 months prior to the fiscal year end.

Standard deviation of the residual from a market model of monthly returns estimated over the fiscal year.

The number of unique business segments the firm operates in during the fiscal year.

Research and development expense scaled by sales during the fiscal year.

Herfindahl-Hirschman measure of industry concentration, in percent, multiplied by $(-1)$, calculated annually based on FamaFrench 12 -industry groups.

Natural log of the total number of firms in the industry, calculated annually based on Fama-French 12-industry groups.

Five-firm concentration ratio, measured as the market share of the five largest firms in the industry based on sales, multiplied by $(-1)$, calculated annually based on Fama-French 12-industry groups. 


\section{Appendix B. Sample Descriptions of Strategic Alliances}

This appendix presents a brief sample description of several of the most common types of strategic alliances studied in this paper. The information for each description is taken from the news or press release used to identify the announcement of the strategic alliance.

\section{B.1. Equity joint venture}

Glanbia PLC, Dairy Farmers of America Inc (DFA), Michigan Milk Producers Association and Foremost Farms USA planned to form a joint venture to build and operate a new cheese and whey production facility in the State of Michigan, USA. Under the agreement, $50 \%$ of the joint venture will be owned by Glanbia and the $50 \%$ balance will be owned by DFA, MMPA and Foremost Farms.

As part of the proposed joint venture DFA, MMPA and Foremost Farms would supply all milk required by the plant while Glanbia will have full responsibility for all commercial, technical and operational aspects of the business. If the project proceeds as planned, commissioning of the new facility is expected to take place in the second half of 2019.

Commenting on the announcement, Brian Phelan, CEO of Glanbia Nutritionals said, "Glanbia is delighted to announce this exciting proposed project in the state of Michigan with DFA, Michigan Milk Producers Association and Foremost Farms. Consistent with Glanbia's growth strategy, this proposed venture will build on our position as the number one producer of American-style cheddar cheese and simultaneously expand our global position as a supplier of advanced technology whey protein to the nutritional sector. This proposed joint venture is a strategic move by all the partners to benefit from the growing, large-scale milk pool in the State of Michigan."

\section{B.2. Marketing alliance}

Kronos Advanced Technologies Inc (KA) and EOL LLC (EL) formed a 5-year strategic alliance wherein KA licensed EL to manufacture, wholesale and market its commercial air products, bacteriological and virus destruction devices and space heaters in Eastern Europe. Under terms of the agreement, EL was expected to give KA a fixed percentage royalty fee on every product sold, as well as upfront licensing and maintenance fees. Specific financial terms were not disclosed.

\section{B.3. Research and development alliance}

Abbott Laboratories (AL) and Neurosearch A/S (NAS) planned to form a strategic alliance (SA) to provide research and development services to commercialize novel compounds for the treatment of a variety of central and peripheral nervous system disorders. The SA gave AL exclusive worldwide sales rights to compounds discovered collaboratively by AL and NAS.

\section{B.4. Technology alliance}

Qualcomm, Inc. granted Northern Telecom, Ltd. a license in which Northern Telecom was to evaluate Qualcomm's Code Division Multiple Access (CDMA) technology for possible use in digital mobile cellular and wireless in-building business telephone systems in Canada. Qualcomm disclosed it had recently completed a trial that verified the technical feasibility of its CDMA systems and demonstrated a subscriber capacity gain of greater that 10 times current analog systems under a variety of conditions, while providing high voice quality. 


\section{B.5. Manufacturing alliance}

Laguna Blends Inc and CannaCeuticals signed a letter of intent whereby Laguna and Canna plan to enter into a definitive Manufacturing and Exclusive Licence Agreement (the "M\&L Agreement") for the purpose of pursuing mutually beneficial business opportunities in the Cannabidiol (CBD) skin care industry. The parties have agreed to an exclusivity period until July 29th in order to negotiate and sign the M\&L Agreement. The LOI contemplates a manufacturing and licensing arrangement that includes the following material terms:

Laguna will purchase the entire existing Canna inventory of 4,500 units for each of the eight existing Canna products for payment of: (i) US\$250,000 (less an initial deposit of US\$24,500 that is payable within 7 days of entry into the M\&L Agreement) on a monthly payment schedule over a six-month period; and (ii) a licence fee of US\$100,000 payable in common shares of the Company at the prior day's closing market price upon entry into the M\&L Agreement. - Laguna will receive an exclusive licence to sell the Canna products for an initial period of two years in the USA and Canada. In addition, Laguna will receive the licence and marketing rights to sell the Canna products in Asia, Europe and Mexico subject to Canna receiving regulatory approval for such sales in those markets and provided Laguna has expanded to those countries. The renewal term is anticipated to be determined at the end of the initial term. - Canna will contribute its research and development expertise in CBD-derived, high quality, Canna skin care products and Canna will continue to manufacture and/or arrange manufacturing for future Canna skin care inventory requirements for Laguna as required. - Laguna will take possession of all of the existing Canna inventory after the initial deposit and licence fee has been paid.

\section{B.6. Licensing alliance}

Amazon.com Inc and Seiki LLC planned to form a strategic alliance wherein Amazon.com Inc and Seiki LLC cross-licensed each other to utilize each others' technology in United States. The strategic alliance

will showcase Amazon Fire TV Edition which will enable native integration of the Fire TV, and will make it possible for viewers to watch live shows and stream movies using an Alexa-powered voice remote. 


\section{Appendix C. Internet Appendix for "Private Communication among Competitors and Public Disclosure"}

This appendix contains additional analyses referenced in my paper, and is organized as follows:

- Analysis of timing of large alliance shocks (Table IA1)

- Cross Sectional analysis of investors' information quality (Table IA2)

- Analysis of strategic alliances and managers' forecast accuracy (Table IA3)

- Analysis of strategic alliances and insider trading (Table IA4)

- Analysis of strategic alliances and information asymmetry among investors (Table IA5)

- Analysis of strategic alliance indicators and public disclosure (Table IA6)

- Analysis of strategic alliance activity and public disclosure indicators (Table IA7)

- Instrumental variable analysis (Table IA8) 


\section{Appendix C. IA Section 1: Variable Definitions}

This appendix provides definitions for the key variables used in my tests.

\begin{tabular}{|c|c|}
\hline \multicolumn{2}{|c|}{ Public disclosure measures } \\
\hline AllianceShock & $\begin{array}{l}\text { Indicator that equals one if the firm is in the top quintile of new } \\
\text { alliances formed in my sample (i.e., whether the firm formed five or } \\
\text { more new strategic alliances for the first time), and zero otherwisel. }\end{array}$ \\
\hline \multicolumn{2}{|c|}{ Public disclosure measures } \\
\hline ForecastAccuracy & $\begin{array}{l}\text { Accuracy of the latest management earnings forecast issued during the } \\
\text { subsequent fiscal year, defined as the absolute value of the latest } \\
\text { forecasted earnings number-or the average if the earnings forecast is } \\
\text { a range- during the year less actual subsequently-announced earnings, } \\
\text { scaled by market capitalization at the end of the fiscal year, multiplied } \\
\text { by }(-1) \text {. }\end{array}$ \\
\hline Forecaster & $\begin{array}{l}\text { Indicator that equals one if management issues a forecast during the } \\
12 \text { months following the fiscal year end, and zero otherwise. }\end{array}$ \\
\hline InsiderBSI & $\begin{array}{l}\text { Insider buy-sell imbalance over the twelve months prior to the end of } \\
\text { the fiscal year, calculated as the number of shares bought by insiders } \\
\text { minus the number of shares sold by insiders, divided by total insider } \\
\text { volume. }\end{array}$ \\
\hline InsiderNPR & $\begin{array}{l}\text { Insider net purchase ratio over the twelve months prior to the end of } \\
\text { the fiscal year, calculated as the number of shares bought by insiders } \\
\text { minus the number of shares sold by insiders, divided by the firm's total } \\
\text { trading volume. }\end{array}$ \\
\hline Spread & $\begin{array}{l}\text { Average daily bid-ask spread during the } 25 \text { trading days following } \\
\text { fiscal year-end. }\end{array}$ \\
\hline \multicolumn{2}{|c|}{ Information quality measures } \\
\hline NAnalyst & $\begin{array}{l}\text { Number of analysts with one-year ahead earnings forecasts on I/B/E/S } \\
\text { as of the end of the fiscal year. }\end{array}$ \\
\hline NInstit & $\begin{array}{l}\text { Number of institutional owners listed on Thomson Reuters as of the } \\
\text { end of the fiscal year. }\end{array}$ \\
\hline AggregateInfoQual & $\begin{array}{l}\text { Measure of the firm's aggregate "peer information" quality during the } \\
\text { year from Shroff, Verdi, and Yost (2017) based on the industry-wide } \\
\text { (i) earnings synchronicity, (ii) total number of analysts, and (iii) } \\
\text { percentage of public firms in each industry-year. }\end{array}$ \\
\hline
\end{tabular}




\section{Appendix C. Table IA1: Timing Test: Large Strategic Alliance Shocks}

This table presents results from regressions of voluntary disclosure on pre- and post-strategic alliance formation indicators for a sample of large strategic alliance formations. AllianceShock is an indicator that equals one if the firm is in the top quintile of new alliances formed in my sample (i.e., whether the firm formed five or more new strategic alliances for the first time), and zero otherwise. All other variables are as defined in Appendix A. Column (1) presents results from including indicators from 4 years prior to the alliance shock up through 3 years after the alliance shock. Each column includes untabulated firm and year fixed effects. $t$-statistics appear in parentheses and are clustered by firm. $*, * *, * * *$ indicate statistical significance (two-sided) at the 0.1, 0.05, and 0.01 levels, respectively. Sample period is $1994-2016$.

\begin{tabular}{lc}
\hline \hline & \\
Dependent Variable: & VolDisc $_{t}$ \\
\cline { 2 - 2 } Variable & $(1)$ \\
\hline & \\
AllianceShock $_{t-4}$ & -0.010 \\
& $(-0.03)$ \\
AllianceShock & -0.276 \\
& $(-0.97)$ \\
AllianceShock $_{t-2}$ & -0.287 \\
& $(-0.99)$ \\
AllianceShock $_{t-1}$ & $-0.543^{* *}$ \\
& $(-2.01)$ \\
AllianceShock $_{t}$ & $-0.438^{*}$ \\
& $(-1.93)$ \\
AllianceShock $_{t+1}$ & $-0.519^{* *}$ \\
& $(-2.31)$ \\
AllianceShock & $-0.486^{* *}$ \\
& $(-2.06)$ \\
AllianceShock & $-0.426^{*+3}$ \\
& $(-1.80)$ \\
\hline Controls & Yes \\
Fixed Effects & Firm \& Year \\
F & 3.92 \\
N & 13,034 \\
\hline \hline
\end{tabular}




\section{Appendix C. Table IA2: Cross Sectional Tests: The Coordination Benefits of Disclosure}

This table presents results from regressions of voluntary disclosure on strategic alliance activity conditional on investors' information quality. All variables are as defined in Appendix and Appendix IA Section 1. Columns (1), (2), and (3) present results using analyst following (NAnalyst), institutional investor following (Ninstit), and aggregate information quality (AggregateInfoQual) from Shroff et al. (2017) to measure InfoQual, respectively. Each model includes untabulated Fama-French 12 industry fixed effects. $t$-statistics appear in parentheses and are clustered by firm. *,**,*** indicate statistical significance (two-sided) at the $0.1,0.05$, and 0.01 levels, respectively. Sample period is $1994-2016$ except for Column (3) of Panel B which requires the necessary data from Shroff et al. (2017) to compute AggregateInfoQual.

\begin{tabular}{|c|c|c|c|}
\hline \multirow{2}{*}{$\begin{array}{l}\text { Dependent Variable: } \\
\text { Measure of InfoQual: } \\
\text { Variable }\end{array}$} & \multicolumn{3}{|c|}{ VolDisc $_{t+1}$} \\
\hline & $\begin{array}{l}\text { NAnalyst } \\
\text { (1) }\end{array}$ & $\begin{array}{c}\text { NInstit } \\
(2)\end{array}$ & $\begin{array}{c}\text { AggregateInfoQual } \\
\text { (3) }\end{array}$ \\
\hline InfoQual $\times \log ($ NewStrategicAlliances) & $\begin{array}{l}-0.072 * * * \\
(-6.61)\end{array}$ & $\begin{array}{l}-0.004 * * * \\
(-8.33)\end{array}$ & $\begin{array}{l}-1.058 * * * \\
(-3.21)\end{array}$ \\
\hline InfoQual & $\begin{array}{l}0.327^{* * * *} \\
(25.62)\end{array}$ & $\begin{array}{l}0.017 * * * \\
(19.86)\end{array}$ & $\begin{array}{l}-1.312 * * * \\
(-7.60)\end{array}$ \\
\hline Log(NewStrategicAlliances) & $\begin{array}{l}-0.624 * * * \\
(-7.71)\end{array}$ & $\begin{array}{l}-0.494 * * * \\
(-5.73)\end{array}$ & $\begin{array}{l}-0.392 * \\
(-1.81)\end{array}$ \\
\hline Controls & & & \\
\hline Size & $\begin{array}{l}0.450^{* * *} \\
(16.00)\end{array}$ & $\begin{array}{l}0.269 * * * \\
(8.58)\end{array}$ & $\begin{array}{l}1.040 * * * \\
(36.30)\end{array}$ \\
\hline SalesVol & $\begin{array}{l}0.394 * * * \\
(2.84)\end{array}$ & $\begin{array}{l}0.277^{*} \\
(1.91)\end{array}$ & $\begin{array}{l}0.384 * * * \\
(2.60)\end{array}$ \\
\hline BTM & $\begin{array}{l}-0.148^{* * * *} \\
(-3.35)\end{array}$ & $\begin{array}{l}-0.291 * * * \\
(-6.37)\end{array}$ & $\begin{array}{l}-0.001 \\
(-0.02)\end{array}$ \\
\hline Leverage & $\begin{array}{l}-0.397^{* *} \\
(-2.51)\end{array}$ & $\begin{array}{l}-0.568 * * * \\
(-3.46)\end{array}$ & $\begin{array}{l}-0.295^{*} \\
(-1.76)\end{array}$ \\
\hline$R O A$ & $\begin{array}{l}0.839^{* * * *} \\
(6.94)\end{array}$ & $\begin{array}{l}1.243^{* * * *} \\
(10.18)\end{array}$ & $\begin{array}{l}0.671 * * * \\
(5.26)\end{array}$ \\
\hline SpecItems & $\begin{array}{l}-2.096^{* * *} \\
(-6.34)\end{array}$ & $\begin{array}{l}-2.434 * * * \\
(-7.25)\end{array}$ & $\begin{array}{l}-2.111^{* * *} \\
(-6.02)\end{array}$ \\
\hline Loss & $\begin{array}{l}0.220^{* * *} \\
(3.10)\end{array}$ & $\begin{array}{l}0.183 * * \\
(2.54)\end{array}$ & $\begin{array}{l}0.159 * * \\
(2.12)\end{array}$ \\
\hline Returns & $\begin{array}{l}0.109^{* * *} \\
(3.83)\end{array}$ & $\begin{array}{l}0.043 \\
(1.59)\end{array}$ & $\begin{array}{l}-0.118 * * * \\
(-4.08)\end{array}$ \\
\hline IdioVol & $\begin{array}{l}-5.225^{* * *} \\
(-17.80)\end{array}$ & $\begin{array}{l}-4.747 * * * \\
(-15.93)\end{array}$ & $\begin{array}{l}-4.476^{* * * *} \\
(-14.88)\end{array}$ \\
\hline NumSegments & $\begin{array}{l}0.153^{* * *} \\
(5.35)\end{array}$ & $\begin{array}{l}0.114^{* * *} \\
(3.83)\end{array}$ & $\begin{array}{l}0.147^{* * * *} \\
(4.62)\end{array}$ \\
\hline$R \& D$-to-Sales & $\begin{array}{l}-0.261^{* * * *} \\
(-13.00) \\
\end{array}$ & $\begin{array}{l}-0.226^{* * *} \\
(-11.16) \\
\end{array}$ & $\begin{array}{l}-0.265^{* * *} \\
(-12.58) \\
\end{array}$ \\
\hline Fixed Effects & Industry & Industry & Industry \\
\hline $\mathrm{F}$ & $219.9^{\circ}$ & 191.4 & $170.7^{\circ}$ \\
\hline $\mathrm{N}$ & 123,893 & 123,893 & 108,088 \\
\hline
\end{tabular}




\section{Appendix C. Table IA3: Strategic Alliances and the Managers' Forecast Accuracy}

This table presents results from regressions of managers' forecast accuracy (ForecastAccuracy) on strategic alliance activity. All variables are as defined in Appendix A and Appendix IA Section 1. Column (1) includes untabulated Fama-French 12 industry fixed effects. Column (2) includes untabulated firm fixed effects. $t$ statistics appear in parentheses and are clustered by firm. *, **,*** indicate statistical significance (twosided) at the 0.1, 0.05, and 0.01 levels, respectively. Sample period is $1994-2016$.

\begin{tabular}{|c|c|c|}
\hline \multirow{2}{*}{$\begin{array}{l}\text { Dependent Variable: } \\
\text { Variable }\end{array}$} & \multicolumn{2}{|c|}{ ForecastAccuracy $t_{t+1}$} \\
\hline & (1) & (2) \\
\hline Log(NewStrategicAlliances) & $\begin{array}{c}0.237 \\
(1.52)\end{array}$ & $\begin{array}{l}-0.005 \\
(-0.33)\end{array}$ \\
\hline \multicolumn{3}{|l|}{ Controls } \\
\hline Size & $\begin{array}{l}-0.019 \\
(-0.16)\end{array}$ & $\begin{array}{l}-0.333 \\
(-1.49)\end{array}$ \\
\hline SalesVol & $\begin{array}{l}-0.448 \\
(-0.58)\end{array}$ & $\begin{array}{l}-1.101 \\
(-0.96)\end{array}$ \\
\hline BTM & $\begin{array}{l}-0.422 \\
(-1.09)\end{array}$ & $\begin{array}{c}-0.969 \\
(-1.39)\end{array}$ \\
\hline Leverage & $\begin{array}{l}-0.773 \\
(-1.03)\end{array}$ & $\begin{array}{l}-0.494 \\
(-1.42)\end{array}$ \\
\hline$R O A$ & $\begin{array}{l}-0.354 \\
(-0.16)\end{array}$ & $\begin{array}{l}-0.932 \\
(-0.90)\end{array}$ \\
\hline SpecItems & $\begin{array}{l}-6.375^{*} \\
(-1.80)\end{array}$ & $\begin{array}{r}0.810 \\
(0.71)\end{array}$ \\
\hline Loss & $\begin{array}{l}-0.371 \\
(-1.05)\end{array}$ & $\begin{array}{r}0.017 \\
(0.32)\end{array}$ \\
\hline Returns & $\begin{array}{l}-0.413 \\
(-1.32)\end{array}$ & $\begin{array}{l}-0.205 \\
(-0.87)\end{array}$ \\
\hline IdioVol & $\begin{array}{l}-4.849 \\
(-1.32)\end{array}$ & $\begin{array}{l}-1.047 \\
(-0.64)\end{array}$ \\
\hline NumSegments & $\begin{array}{c}0.058 \\
(1.51)\end{array}$ & $\begin{array}{r}0.077 \\
(0.60)\end{array}$ \\
\hline$R \& D$-to-Sales & $\begin{array}{l}-1.407 \\
(-0.89) \\
\end{array}$ & $\begin{array}{r}0.381 \\
(0.85) \\
\end{array}$ \\
\hline Fixed Effects & Industry & Firm \\
\hline $\mathrm{F}$ & 1.197 & 0.858 \\
\hline $\mathrm{N}$ & 17,098 & 17,098 \\
\hline
\end{tabular}




\section{Appendix C. Table IA4: Strategic Alliances and Managers' Private Information}

This table presents results from regressions of insider trading activity on the firms' strategic alliance activity. All variables are as defined in Appendix A and Appendix IA Section 1. Columns (1) and (3) include untabulated Fama-French 12 industry fixed effects. Columns (2) and (4) include untabulated firm fixed effects. Columns (1) and (2) present results using the insider buy-sell imbalance over the twelve months prior to fiscal year-end to measure insider trading activity (InsiderBSI). Columns (3) and (4) present results using insider net purchase ratio of insider buy-sell imbalance scaled by total trading volume over the twelve months prior to fiscal year-end as an alternative measure of insider trading activity (InsiderNPR). $t$-statistics appear in parentheses and are clustered by firm. *, **,*** indicate statistical significance (two-sided) at the 0.1 , 0.05, and 0.01 levels, respectively. Sample period is $1994-2016$.

\begin{tabular}{|c|c|c|c|c|}
\hline \multirow{2}{*}{$\begin{array}{l}\text { Dependent Variable: } \\
\text { Variable }\end{array}$} & \multicolumn{2}{|c|}{ Insider $B S I_{t}$} & \multicolumn{2}{|c|}{ Insider $N P R_{t}$} \\
\hline & (1) & (2) & (3) & (4) \\
\hline Log(NewStrategicAlliances) & $\begin{array}{l}0.055^{* * *} \\
(8.40)\end{array}$ & $\begin{array}{l}0.022 * * * \\
(4.05)\end{array}$ & $\begin{array}{l}0.082 * * * \\
(7.51)\end{array}$ & $\begin{array}{l}-0.011 \\
(-0.98)\end{array}$ \\
\hline \multicolumn{5}{|l|}{ Controls } \\
\hline Size & $\begin{array}{l}-0.102 * * * \\
(-50.41)\end{array}$ & $\begin{array}{l}-0.204 * * * \\
(-54.31)\end{array}$ & $\begin{array}{l}-0.064^{* * *} \\
(-20.10)\end{array}$ & $\begin{array}{l}-0.168^{* * *} \\
(-21.21)\end{array}$ \\
\hline SalesVol & $\begin{array}{l}-0.047 * * * \\
(-3.56)\end{array}$ & $\begin{array}{l}-0.012 \\
(-0.55)\end{array}$ & $\begin{array}{l}-0.296^{* * *} \\
(-9.69)\end{array}$ & $\begin{array}{l}-0.294 * * * \\
(-5.64)\end{array}$ \\
\hline$B T M$ & $\begin{array}{l}0.124 * * * \\
(25.90)\end{array}$ & $\begin{array}{l}0.075^{* * *} \\
(13.45)\end{array}$ & $\begin{array}{l}0.203^{* * *} \\
(24.59)\end{array}$ & $\begin{array}{l}0.182^{* * *} \\
(15.77)\end{array}$ \\
\hline Leverage & $\begin{array}{l}0.247^{* * *} \\
(18.09)\end{array}$ & $\begin{array}{l}0.104^{* * *} \\
(5.80)\end{array}$ & $\begin{array}{l}0.459^{* * *} \\
(18.17)\end{array}$ & $\begin{array}{l}0.422^{* * *} \\
(10.63)\end{array}$ \\
\hline$R O A$ & $\begin{array}{l}-0.058^{* * *} \\
(-3.65)\end{array}$ & $\begin{array}{l}-0.028 \\
(-1.49)\end{array}$ & $\begin{array}{l}-0.378^{* * *} \\
(-11.11)\end{array}$ & $\begin{array}{l}-0.246^{* * *} \\
(-5.61)\end{array}$ \\
\hline SpecItems & $\begin{array}{l}0.128^{* * *} \\
(3.12)\end{array}$ & $\begin{array}{c}0.040 \\
(0.88)\end{array}$ & $\begin{array}{l}0.537^{* * *} \\
(6.30)\end{array}$ & $\begin{array}{l}0.302^{* * *} \\
(3.11)\end{array}$ \\
\hline Loss & $\begin{array}{l}0.116^{* * *} \\
(17.06)\end{array}$ & $\begin{array}{l}0.077^{* * * *} \\
(11.32)\end{array}$ & $\begin{array}{l}0.172 * * * \\
(12.80)\end{array}$ & $\begin{array}{l}0.145^{* * *} \\
(10.20)\end{array}$ \\
\hline Returns & $\begin{array}{l}-0.028^{* * *} \\
(-8.30)\end{array}$ & $\begin{array}{l}-0.003 \\
(-0.77)\end{array}$ & $\begin{array}{l}-0.157^{* * *} \\
(-15.96)\end{array}$ & $\begin{array}{l}-0.120^{* * *} \\
(-11.68)\end{array}$ \\
\hline IdioVol & $\begin{array}{l}0.107^{* * *} \\
(3.22)\end{array}$ & $\begin{array}{l}0.187^{* * *} \\
(5.46)\end{array}$ & $\begin{array}{l}-0.815^{* * *} \\
(-10.17)\end{array}$ & $\begin{array}{l}-0.635^{* * *} \\
(-7.04)\end{array}$ \\
\hline NumSegments & $\begin{array}{l}0.007^{* * *} \\
(3.71)\end{array}$ & $\begin{array}{c}0.002 \\
(0.68)\end{array}$ & $\begin{array}{l}0.029^{* * *} \\
(9.49)\end{array}$ & $\begin{array}{l}0.027^{* * *} \\
(5.69)\end{array}$ \\
\hline$R \& D$-to-Sales & $\begin{array}{l}0.010^{* * *} \\
(3.44)\end{array}$ & $\begin{array}{l}0.010^{* * *} \\
(2.70)\end{array}$ & $\begin{array}{r}0.008 \\
(1.54)\end{array}$ & $\begin{array}{r}0.004 \\
(0.63)\end{array}$ \\
\hline Fixed Effects & Industry & Firm & Industry & Firm \\
\hline $\mathrm{F}$ & 713.4 & 506.7 & 241.8 & 183.1 \\
\hline $\mathrm{N}$ & 124,598 & 124,598 & 124,598 & 124,598 \\
\hline
\end{tabular}




\section{Appendix C. Table IA5: Strategic Alliances and Information Asymmetry}

This table presents results from regressions of information asymmetry among investors on strategic alliance activity. All variables are as defined in Appendix A and Appendix IA Section 1. Columns (1) includes untabulated Fama-French 12 industry fixed effects. Column (2) includes untabulated firm fixed effects. $t$ statistics appear in parentheses and are clustered by firm. *,**,*** indicate statistical significance (twosided) at the 0.1, 0.05, and 0.01 levels, respectively. Sample period is $1994-2016$.

\begin{tabular}{|c|c|c|}
\hline \multirow{2}{*}{$\begin{array}{l}\text { Dependent Variable: } \\
\text { Variable }\end{array}$} & \multicolumn{2}{|c|}{ Spread $_{t+1}$} \\
\hline & $(1)$ & (2) \\
\hline Log(NewStrategicAlliances) & $\begin{array}{l}0.006^{* * *} \\
(21.47)\end{array}$ & $\begin{array}{l}0.001 * * * \\
(5.75)\end{array}$ \\
\hline Controls & & \\
\hline Size & $\begin{array}{l}-0.010^{* * *} \\
(-79.63)\end{array}$ & $\begin{array}{l}-0.013 * * * \\
(-60.68)\end{array}$ \\
\hline SalesVol & $\begin{array}{l}0.001 * * \\
(1.99)\end{array}$ & $\begin{array}{l}0.003 * * * \\
(3.11)\end{array}$ \\
\hline BTM & $\begin{array}{l}0.002^{* * * *} \\
(6.36)\end{array}$ & $\begin{array}{l}0.002 * * * \\
(5.35)\end{array}$ \\
\hline Leverage & $\begin{array}{l}0.011^{* * *} \\
(14.67)\end{array}$ & $\begin{array}{r}0.001 \\
(0.91)\end{array}$ \\
\hline$R O A$ & $\begin{array}{l}-0.004 * * * \\
(-3.50)\end{array}$ & $\begin{array}{l}-0.003^{* * * *} \\
(-3.26)\end{array}$ \\
\hline SpecItems & $\begin{array}{l}0.005^{*} \\
(1.93)\end{array}$ & $\begin{array}{c}0.000 \\
(0.12)\end{array}$ \\
\hline Loss & $\begin{array}{l}-0.001 * * * \\
(-3.30)\end{array}$ & $\begin{array}{l}-0.001 * * * \\
(-3.67)\end{array}$ \\
\hline Returns & $\begin{array}{l}-0.006^{* * * *} \\
(-34.58)\end{array}$ & $\begin{array}{l}-0.003 * * * \\
(-23.57)\end{array}$ \\
\hline IdioVol & $\begin{array}{l}0.029 * * * \\
(15.22)\end{array}$ & $\begin{array}{l}0.012^{* * *} \\
(8.00)\end{array}$ \\
\hline NumSegments & $\begin{array}{l}0.000 * * * \\
(4.53)\end{array}$ & $\begin{array}{l}-0.000 \\
(-1.30)\end{array}$ \\
\hline$R \& D$-to-Sales & $\begin{array}{l}-0.001 * * * \\
(-9.99)\end{array}$ & $\begin{array}{l}-0.000 \\
(-0.35)\end{array}$ \\
\hline $\begin{array}{l}\text { Fixed Effects } \\
\text { F }\end{array}$ & $\begin{array}{c}\text { Industry } \\
963.4 \\
123893\end{array}$ & $\begin{array}{c}\text { Firm } \\
602.3 \\
\end{array}$ \\
\hline
\end{tabular}




\section{Appendix C. Table IA6: Strategic Alliance Indicators and Voluntary Disclosure}

This table presents results from regressions of voluntary disclosure on indicators for whether the firm formed at least one strategic alliance during the fiscal year. All variables are as defined in Appendix A. Columns (1) presents results using my main quantitative measure of public disclosure, VolDisc, and Columns (2) presents results using my main qualitative measure of public disclosure, ProductionDisc. Each column includes untabulated Fama-French 12 industry fixed effects. $t$-statistics appear in parentheses and are clustered by firm. ${ }^{*}, * *, * *$ indicate statistical significance (two-sided) at the $0.1,0.05$, and 0.01 levels, respectively. Sample period is $1994-2016$.

\begin{tabular}{|c|c|c|}
\hline \multirow{3}{*}{$\begin{array}{l}\text { Dependent Variable: } \\
\text { Variable }\end{array}$} & & ProductionDisc $_{t}$ \\
\hline & VolDisc $_{t+1}$ & +1 \\
\hline & (1) & (2) \\
\hline NewStrategicAlliance & $\begin{array}{l}-0.976 * * * \\
(-9.58)\end{array}$ & $\begin{array}{l}-0.122 * * * \\
(-3.98)\end{array}$ \\
\hline \multicolumn{3}{|l|}{ Controls } \\
\hline Size & $\begin{array}{l}1.008 * * * \\
(36.18)\end{array}$ & $\begin{array}{l}0.253 * * * \\
(29.54)\end{array}$ \\
\hline SalesVol & $\begin{array}{l}0.452 * * * \\
(3.02)\end{array}$ & $\begin{array}{l}0.370^{* * * *} \\
(8.89)\end{array}$ \\
\hline BTM & $\begin{array}{l}-0.128 * * * \\
(-2.65)\end{array}$ & $\begin{array}{l}0.032^{*} \\
(1.78)\end{array}$ \\
\hline Leverage & $\begin{array}{l}-0.255 \\
(-1.51)\end{array}$ & $\begin{array}{l}0.380 * * * \\
(7.90)\end{array}$ \\
\hline$R O A$ & $\begin{array}{l}0.910^{* * *} \\
(7.08)\end{array}$ & $\begin{array}{l}-0.508^{* * * *} \\
(-9.49)\end{array}$ \\
\hline SpecItems & $\begin{array}{l}-2.639^{* * *} \\
(-7.57)\end{array}$ & $\begin{array}{r}0.026 \\
(0.20)\end{array}$ \\
\hline Loss & $\begin{array}{l}0.156^{* *} \\
(2.10)\end{array}$ & $\begin{array}{l}0.369^{* * *} \\
(16.97)^{2}\end{array}$ \\
\hline Returns & $\begin{array}{l}-0.175^{* * *} \\
(-6.25)\end{array}$ & $\begin{array}{l}0.053 * * * \\
(5.35)\end{array}$ \\
\hline IdioVol & $\begin{array}{l}-4.563^{* * *} \\
(-14.81)\end{array}$ & $\begin{array}{r}0.006 \\
(0.06)\end{array}$ \\
\hline NumSegments & $\begin{array}{l}0.112^{* * * *} \\
(3.59)\end{array}$ & $\begin{array}{l}-0.051 * * * \\
(-6.01)\end{array}$ \\
\hline$R \& D$-to-Sales & $\begin{array}{l}-0.279 * * * \\
(-13.11)\end{array}$ & $\begin{array}{l}-0.002 \\
(-0.22) \\
\end{array}$ \\
\hline Fixed Effects & Industry & Industry \\
\hline $\mathrm{F}$ & $204.6^{\circ}$ & 115,230 \\
\hline $\mathrm{N}$ & 123,893 & 158.8 \\
\hline
\end{tabular}




\section{Appendix C. Table IA7: Strategic Alliances and Voluntary Disclosure Indicators}

This table presents results from regressions of a voluntary disclosure indicator (Forecaster) on strategic alliance activity during the fiscal year. All variables are as defined in Appendix A. Columns (1) presents results using my main quantitative measure of public disclosure, VolDisc, and Columns (2) presents results using my main qualitative measure of public disclosure, ProductionDisc. Each column includes untabulated Fama-French 12 industry fixed effects. $t$-statistics appear in parentheses and are clustered by firm. *, **, *** indicate statistical significance (two-sided) at the 0.1, 0.05, and 0.01 levels, respectively. Sample period is $1994-2016$.

\begin{tabular}{lc}
\hline \hline & \\
Dependent Variable: & Forecaster $_{t+1}$ \\
\cline { 2 - 2 } Variable & $(1)$ \\
\hline Log(NewStrategicAlliances) & $-0.075^{* * *}$ \\
& $(-13.04)$ \\
Controls & \\
Size & $0.088^{* * *}$ \\
& $(51.54)$ \\
SalesVol & $0.060^{* * *}$ \\
& $(6.31)$ \\
BTM & 0.005 \\
& $(1.46)$ \\
Leverage & $-0.027^{* *}$ \\
& $(-2.54)$ \\
ROA & $0.091^{* * *}$ \\
& $(9.48)$ \\
SpecItems & $-0.286^{* * *}$ \\
Loss & $(-11.20)$ \\
& $0.020^{* * *}$ \\
Returns & $(4.16)$ \\
IdioVol & $-0.030^{* * *}$ \\
NumSegments & $(-14.32)$ \\
R\&D-to-Sales & $0.106^{* * *}$ \\
Fixed Effects & $(5.02)$ \\
F & $0.006^{* * *}$ \\
N & $(2.91)$ \\
\hline
\end{tabular}




\section{Appendix C. Table IA8: Instrumental Variables Analysis-Combined Reporting Rules}

This table presents results from a two-stage least squares procedure using state adoption of combined reporting rules as an instrument for strategic alliance activity, following Bodnaruk, Massa, and Simonov (2013) and Li, Qiu, and Wang (2018), as a shock to the benefits of forming strategic alliances. CombinedReportingState is an indicator equal to one if the firm is headquartered in a state that has adopted combined reporting rules, and zero otherwise, using firms' state of headquarter data from Jennings, Lee, and Matsumoto (2017). All other variables are as defined in Appendix A. Panel A present results from the first stage estimation and Panel B presents results from the second stage estimation. Each model includes untabulated firm and year fixed effects. $t$-statistics appear in parentheses and are clustered by firm. *, **, *** indicate statistical significance (two-sided) at the 0.1, 0.05, and 0.01 levels, respectively. Sample period is $1994-2012$.

\section{Panel A. Instrumental Variable: First Stage}

\begin{tabular}{lc} 
Dependent Variable: & Log(NewStrategicAlliances) \\
\cline { 2 - 2 } Variable & $(1)$ \\
\hline \multirow{2}{*}{ CombinedReportingState } & $0.029^{* * *}$ \\
Controls & $(2.98)$ \\
Size & $0.047^{* * *}$ \\
SalesVol & $(14.18)$ \\
& 0.021 \\
BTM & $(1.58)$ \\
& $0.020^{* * *}$ \\
Leverage & $(5.75)$ \\
& 0.005 \\
ROA & $(0.39)$ \\
SpecItems & $-0.071^{* * *}$ \\
Loss & $(-4.78)$ \\
& $0.083^{* * *}$ \\
Returns & $(2.82)$ \\
& $0.015^{* * *}$ \\
IdioVol & $(3.58)$ \\
NumSegments & $-0.013^{* * *}$ \\
R\&D-to-Sales & $(-5.62)$ \\
& $0.075^{* * *}$ \\
Fixed Effects & $(3.41)$ \\
$\mathrm{N}$ & $-0.008^{* * *}$ \\
\hline \hline
\end{tabular}




\section{Appendix C. Table IA8: Instrumental Variables Analysis-Combined Reporting Rules (cont'd)}

Panel B. Instrumental Variable: Second Stage

\begin{tabular}{lc}
\hline & \\
Dependent Variable: & VolDisc $_{t}$ \\
\cline { 2 - 2 } Variable & $(1)$ \\
\hline Instrumented from first stage: & \\
& \\
Log(NewStrategicAlliances) & $-11.917^{*}$ \\
& $(-1.78)$ \\
\hline Controls & Yes \\
Fixed Effects & Firm \& Year \\
$\mathrm{F}$ & 34.45 \\
$\mathrm{~N}$ & 106,517 \\
\hline \hline
\end{tabular}




\section{BIBLIOGRAPHY}

Ali, A., Klasa, S., and Yeung, E., 2014. Industry concentration and corporate disclosure policy. Journal of Accounting and Economics, 58.2-3: 240-264.

Anand, B. and Khanna, T., 2000. Do firms learn to create value? The case of alliances. Strategic Management Journal, 21.3: 295-315.

Anderson, S., Christ, M., Dekker, H., and Sedatole, K., 2014. The use of management controls to mitigate risk in strategic alliances: field and survey evidence. Journal of Management Accounting Research, 26.1: 1-32.

Anderson, S., Christ, M., Dekker, H., and Sedatole, K., 2015. Do extant management control frameworks fit the alliance setting? A descriptive analysis. Industrial Marketing Management, 46: 36-53.

Anderson, S. and Dekker, H., 2014. The role of management controls in transforming firm boundaries and sustaining hybrid organizational forms. Foundations and Trends ${ }^{\circledR}$ in Accounting, 8.2: 75-141.

Armstrong, C., Glaeser, S., Huang, S., and Taylor, D., 2018. The economics of managerial taxes and corporate risk-taking. The Accounting Review, forthcoming.

Armstrong, C., Glaeser, S., and Kepler, J., 2017. Strategic reactions in corporate tax planning. Working paper.

Armstrong, C., Guay, W., and Weber, J., 2010. The role of information and financial reporting in corporate governance and debt contracting. Journal of Accounting and Economics, 50.2: 179-234.

Arslan, B., 2017. The interplay of competitive and cooperative behavior and differential benefits in alliances. Strategic Management Journal, forthcoming.

Arya, A. and Mittendorf, B., 2016. On the synergy between disclosure and investment beauty contests. Journal of Accounting and Economics, 61:2-3: 255-273.

ASAP, 2013. The ASAP Handbook of Alliance Management (3rd edition). The Association of Strategic Alliance Professionals, 33-34.

Baker, G., Gibbons, R., and Murphy, K., 2008. Strategic alliances: bridges between islands of conscious power. Journal of the Japanese and International Economies, 22.2: $146-163$

Balakrishnan, S. and Koza, M., 1993. Information asymmetry, adverse selection and jointventures: theory and evidence. Journal of Economic Behavior and Organization, 20.1: 99-117.

Bamford, J., December 5, 2017. The importance of joint ventures - three snapshots. Water Street Partners. Available at www.waterstreetpartners.net/infographic/corporateinvestments-the-importance-of-joint-ventures-at-the-company-industry-andgeographic-level. 
Bertomeu, J., Evans, J., Feng, M., and Tseng, A., 2015. Tacit collusion and voluntary disclosure: theory and evidence from the US automotive industry. Working paper.

Bertomeu, J. and Liang, P., 2015. Disclosure policy and industry fluctuations. Management Science, 61.6: 1292-1305.

Bloomfield, M., 2018. Compensation disclosures and the weaponization of executive pay: evidence from revenue-based performance evaluation. Working paper.

Bodnaruk, A., Massa, M., and Simonov, A., 2013. Alliances and corporate governance. Journal of Financial Economics, 107.3: 671-693.

Bourveau, T., She, G., and Žaldokas, A., 2018. Corporate disclosure as a tacit coordination mechanism: evidence from cartel enforcement regulations. Working paper.

Bushee, B., Keusch, T., and Kim, J., 2019. Co-opetition and the Firm's Information Environment. Working paper.

Clinch, G., and Verrecchia, R., 1997. Competitive disadvantage and discretionary disclosure in industries. Australian Journal of Management, 22.2: 125-137.

Dye, R., 1985. Disclosure of nonproprietary information. Journal of Accounting Research, 23.1: 123-145.

Dyer, J., Kale, P., and Singh, H., 2001. How to make strategic alliances work. MIT Sloan Management Review, 42.4: 37.

Dyreng, S., Lindsey, B., and Thornock, J., 2013. Exploring the role Delaware plays as a domestic tax haven. Journal of Financial Economics, 108.3: 751-772.

Fich, E., Starks, L., and Yore, A., 2014. CEO deal-making activities and compensation. Journal of Financial Economics, 114.3: 471-492.

Fried, D., 1984. Incentives for information production and disclosure in a duopolistic environment. Quarterly Journal of Economics, 99.2: 367-381.

FTC, 2011. Antitrust issues related to benchmarking and other information exchanges. Remarks of Thomas Rosch before the ABA section of antitrust law. Available at www.ftc.gov/sites/default/files/documents/public statements/antitrust-issuesrelated-benchmarking-and-other-informationexchanges/110503roschbenchmarking.pdf.

Gibbons, R. and Roberts, J., 2013. Handbook of Organizational Economics. Princeton University Press.

Gigler, F., 1994. Self-enforcing voluntary disclosures. Journal of Accounting Research, 32.2: 224-240.

Glaeser, S., 2018. The effects of proprietary information on corporate disclosure and transparency: evidence from trade secrets. Journal of Accounting \& Economics, 66.1: 163-193.

Gomes-Casseres, B., Hagedoorn, J., and Jaffe, A., 2006. Do alliances promote knowledge flows? Journal of Financial Economics, 80.1: 5-33. 
Guay, W., Samuels, D. and Taylor, D., 2016. Guiding through the fog: financial statement complexity and voluntary disclosure. Journal of Accounting and Economics, 62.23: 234-269.

Gulati, R. and Singh, H., 1998. The architecture of cooperation: managing coordination costs and appropriation concerns in strategic alliances. Administrative Science Quarterly, 43.4: 781-814.

Henry, E. and Leone, A., 2015. Measuring qualitative information in capital markets research: comparison of alternative methodologies to measure disclosure tone. The Accounting Review, 91.1: 153-178.

Inkpen, A. and Beamish, P., 1997. Knowledge, bargaining power, and the instability of international joint ventures. Academy of Management Review, 22.1: 177-202.

Jennings, J., Lee, J., and Matsumoto, D., 2017. The effect of industry co-location on analysts' information acquisition costs. The Accounting Review, 92.6: 103-127.

Jensen, M. and Meckling, W., 1992. Specific and general knowledge and organizational structure. In Contract Economics, (Werin and Wijkander, editors). Oxford, U.K.: Blackwell Publishers.

J.P. Morgan, 2017. 2017 M\&A global outlook. Available at www.jpmorgan.com/global/ cib/investment-banking/2017-ma-global-outlook.

Jung, W. and Kwon, Y., 1988. Disclosure when the market is unsure of information endowment of managers. Journal of Accounting Research, 26.1: 146-153.

Kale, P., Singh, H., and Perlmutter, H., 2000. Learning and protection of proprietary assets in strategic alliances: building relational capital. Strategic Management Journal, 21.3: 217-237.

Kogut, B., 1988. Joint ventures: Theoretical and empirical perspectives. Strategic Management Journal, 9.4: 319-332.

Lang, M. and Sul, E., 2014. Linking industry concentration to proprietary costs and disclosure: challenges and opportunities. Journal of Accounting and Economics, 58.2-3: 265-274.

Leuz, C and Wysocki, P., 2016. The economics of disclosure and financial reporting regulation: evidence and suggestions for future research. Journal of Accounting Research, 54.2: 525-622.

Li, K., Qiu, J., and Wang, J., 2018. Technological competition and strategic alliances. Management Science, forthcoming.

Loughran, T. and McDonald, B., 2016. Textual analysis in accounting and finance: a survey. Journal of Accounting Research, 54.4: 1187-1230.

Mazerov, M., 2002. Closing three common corporate income tax loopholes could raise additional revenue for many states. State Tax Notes, 24: 421-434. 
Mazerov, M., 2009. A majority of states have now adopted a key corporate tax reform "combined reporting." Center on Budget and Policy Priorities.

Ménard, C., 2004. The economics of hybrid organizations. Journal of Institutional and Theoretical Economics, 160.3: 345-376.

NERA, 2014. Competition policy applied to information exchanges between competitors in the EU: proceedings of the Spanish competition authority in a recent case. Available

at www.nera.com/content/dam/nera/publications/2014/PUB_English_Intercambios Info_Entre_Competidores_Spain_Eng_1214.pdf.

OECD, 2010. Information exchanges between competitors under competition law. Policy Roundtables. Available at www.oecd.org/competition/cartels/48379006.pdf.

Parkhe, A., 1993. Strategic alliance structuring: a game theoretic and transaction cost examination of interfirm cooperation. Academy of Management Journal, 36.4: 794829.

PwC, 2016. Strategic alliances: examining the keys to success. Available at www.pwc.com/ us/en/deals/publications/assets/pwc-deals-joint-venturesstrategic-alliances.pdf.

Reis, R. and Stocken, P., 2007. Strategic consequences of historical cost and fair value measurements. Contemporary Accounting Research, 24.2: 557-584.

Reuer, J. and Koza, M., 2000. Asymmetric information and joint venture performance: theory and evidence for domestic and international joint ventures. Strategic Management Journal, 21.1: 81-88.

Robinson, D., 2008. Strategic alliances and the boundaries of the firm. Review of Financial Studies, 21.2: 649-681.

Robinson, D. and Stuart, T., 2007. Financial contracting in biotech strategic alliances. Journal of Law and Economics, 50.3: 559-596.

Saul, J. and Wallis, K., March 21, 2017. Container shipping lines ordered to testify in U.S. sector probe. Reuters. Available at www.reuters.com/article/us-usashippers/container-shipping-lines-ordered-to-testify-in-u-s-sector-probeidUSKBN16S2L6.

Schoenfeld, J., 2018. Shareholder-manager contracts in public companies. Working paper.

Seru, A., 2014. Firm boundaries matter: evidence from conglomerates and R\&D activity. Journal of Financial Economics, 111.2: 381-405.

Simonin, B., 1999. Ambiguity and the process of knowledge transfer in strategic alliances. Strategic Management Journal, 20.7: 595-623.

Teece, D., 1992. Competition, cooperation, and innovation: organizational arrangements for regimes of rapid technological progress. Journal of Economic Behavior and Organization, 18.1: 1-25. 
Thomas, J. and Trevino, L., 1993. Information processing in strategic alliance building: a multiple-case approach. Journal of Management Studies, 30.5: 779-814.

Verrecchia, R., 1990. Information quality and discretionary disclosure. Journal of Accounting and Economics, 12.4: 365-380.

Vives, X., 1984. Duopoly information equilibrium: Cournot and Bertrand. Journal of Economic Theory, 34.1: 71-94.

Williamson, O., 1975. Markets and Hierarchies: Analysis and Antitrust Implications. The Free Press: A Division of Macmillan Publishing Co., Inc.

Williamson, O., 1985. The Economic Institutions of Capitalism. Simon and Schuster.

Williamson, O., 1991. Comparative economic organization: the analysis of discrete structural alternatives. Administrative Science Quarterly, 36.2: 269-296. 